\title{
Response of algal-bacterial granular system to low carbon wastewater: Focus on granular stability, nutrients removal and accumulation
}

Ziwen Zhao ${ }^{\text {a }}$ Xiaojing Yang ${ }^{\mathrm{a}}$, Wei Cai ${ }^{\mathrm{b}}$, Zhongfang Lei ${ }^{\mathrm{a}, *}$, Kazuya Shimizu ${ }^{\mathrm{a}}$, Zhenya Zhang $^{\mathrm{a}}$, Motoo Utsumi ${ }^{\mathrm{a}}$, Duu-Jong Lee ${ }^{\mathrm{c}}$

${ }^{\mathrm{a}}$ Graduate School of Life and Environmental Sciences, University of Tsukuba, 1-1-1

Tennodai, Tsukuba, Ibaraki 305-8572, Japan

${ }^{\mathrm{b}}$ College of Biological and Agricultural Engineering, Jilin University, Changchun 130022, China

'Department of Chemical Engineering, National Taiwan University, Taipei 106, Taiwan

*Corresponding author. Email address: lei.zhongfang.gu@u.tsukuba.ac.jp (Z. Lei) 


\begin{abstract}
The effect of influent chemical oxygen demand to nitrogen $(\mathrm{COD} / \mathrm{N})$ ratio on the granular stability, nutrients removal and accumulation of the algal-bacterial AGS was investigated. Two sequencing batch reactors were operated under different influent $\mathrm{COD} / \mathrm{N}$ ratio, i.e., $\mathrm{R}_{1}$ (control, $\left.\mathrm{COD} / \mathrm{N}=8\right)$ and $\mathrm{R}_{2}$ : $(\mathrm{COD} / \mathrm{N}=8,4,2$, and 1 through stepwise decrease of COD). Results showed that the integrity coefficient of the granules in $\mathrm{R}_{2}$ stabilized at $0.7-5.4 \%$ during the whole operation. Significantly enhanced dissolved inorganic carbon (DIC) uptake and the faster growth of algae indicated the great potential for reduction in greenhouse gases (GHGs) emission by using the algal-bacterial AGS system. The algal-bacterial AGS biomass contained high phosphorus (P) and $\mathrm{N}$ contents as well as extremely high P bioavailability (up to 98\%) which could be easily used for resource recovery. Loosely bound extracellular polymeric substances (LB-EPS) might be the key factor to control the deterioration of granular stability in this system.
\end{abstract}

Keywords: Algal-bacterial aerobic granular sludge (AGS); Low carbon wastewater; Granular stability; Nutrients removal; Nutrients accumulation 


\section{Introduction}

Aerobic granular sludge (AGS) is regarded as one of the most promising biotechnologies for wastewater treatment due to its unique features such as dense and compact structure, excellent settleability, and high tolerance to toxicity and loading rate (van Loosdrecht and Brdjanovic, 2014; Pronk et al., 2015). During the past decades, AGS technology has been proven to be a suitable solution for the treatment of domestic and industrial wastewaters. Despite the significant advancements in the development of AGS process, loss of granular stability during long-term operation is still one of the most crucial barriers to its practical applications (Zhang et al., 2016a). Lee et al. (2010) pointed out the problems regarding the instability of granules and summarized some mechanisms involved, including outgrowth of filamentous organisms, hydrolysis of the anaerobic core, function loss of some strains, decrease in extracellular polymeric substances (EPS), and so on. So far, the mechanisms behind the loss of AGS stability have not been fully understood.

On the other hand, biological wastewater treatment is not so efficient in nutrients $(\mathrm{N}$ and P) removal due to the lack of carbon source (Gong et al., 2018). Many innovations have been attempted to enhance the nutrients removal in municipal wastewater treatment plants (WWTPs) with reduced consumption of carbon source, like two-sludge system (Wang et al., 2017) or coupling electrolysis with an anaerobic-anoxic-oxic $\left(\mathrm{A}^{2} / \mathrm{O}\right)$ reactor (Gong et al., 2018). As it is known, chemical oxygen demand (COD)/N ratio of wastewater is an important operation parameter for the stable operation of biotechnologybased WWTPs, which might affect granular stability. A previous study explored the 
impact of COD/N ratio on AGS disintegration (Luo et al., 2014). Their results showed that decrease in $\mathrm{COD} / \mathrm{N}$ ratio from 4 to 1 brought about the reduction of net tyrosine production in EPS and the shift of major microbial communities, leading to the decreases in nitrification efficiency and physical strength, size and settleability of AGS, thus the collapse of AGS structure. Moreover, Kocaturk and Erguder (2016) claimed that in terms of high COD and total ammonia nitrogen (TAN) removals and granular stability, the optimum $\mathrm{COD} / \mathrm{N}$ ratio was about 7.5. These results indicate that insufficient carbon source might limit the application of AGS into practice.

Algal-bacterial symbiosis system has been considered as a good alternative to conventional activated sludge process (ASP), because it possesses many advantages like lower energy demand for degradation of organic matter, enhanced nutrients removal, and more potential for resources recovery (Quijano et al., 2017). In this symbiosis system, algae growth generates oxygen which is required by aerobic bacteria for degradation of organic matter; at the same time nutrients and carbon dioxide $\left(\mathrm{CO}_{2}\right)$ produced from oxidation can be assimilated by algae (Santiago et al., 2013). In this context, the requirement of carbon source for nutrients removal might be reduced owing to the coexistence of algae in the symbiosis system. Previous works indicate that algae could coexist with activated sludge or AGS (Abdel-Raouf et al., 2012; Huang et al., 2015a; Li et al., 2015), and the resultant symbiosis system reflects a prospective option for future wastewater treatment resulting in less energy consumption and more nutrients uptake or removal by algae. In addition, the algal-bacterial granular symbiosis system can be successfully achieved by using mature AGS (Liu et al., 2017) or 50\% (w/w) algalbacterial granules in continuous-flow reactors (Ahmad et al., 2017). Most recently, Zhang 
et al. (2018) and Liu et al. (2018) claimed that enhanced system stability and improved nutrients removal efficiency could be achieved by using the algal-bacterial consortium in lab-scale photobioreactors.

Up to the present, however, the impact of carbon source on the new algal-bacterial AGS system has not been paid much attention, even though this system is most promising for enhanced nutrients removal with less carbon source requirement and lower energy consumption. Moreover, very little information is available regarding the influence of wastewater $\mathrm{COD} / \mathrm{N}$ ratio on granular stability in the algal-bacterial AGS system, let alone the changes in nutrients removal and accumulation during the treatment of low COD/N wastewaters which always happen in municipal wastewater and/or its combination with industrial wastewaters.

This study aimed to investigate the effect of decrease in wastewater COD/N ratio (from 8 to 1) on the granular stability, nutrients removal and accumulation of the algalbacterial AGS. The granules' morphology, strength and extracellular polymeric substances (EPS) content were observed and analyzed. In addition, nutrients ( $\mathrm{P}$ and $\mathrm{N})$ accumulation and $\mathrm{P}$ bioavailability in algal-bacterial granules were explored. Results from this work are expected to provide scientific reference and guidance for the operation and maintenance of this novel AGS system.

\section{Materials and methods}

\subsection{Seed sludge and synthetic wastewater}


The seeded mature algal-bacterial AGS used in this study were collected from a laboratory-scale sequencing batch reactor (SBR). This reactor has been stably operated for 55 days. The initial biomass concentrations in the two reactors $\left(\mathrm{R}_{1}\right.$ for control and $\mathrm{R}_{2}$ for testing) were around $4.14 \pm 0.03 \mathrm{~g} / \mathrm{L}$ of mixed liquor volatile suspended solids (MLVSS) with sludge volume index $\left(\mathrm{SVI}_{5}\right)$ of $37.9 \pm 0.3 \mathrm{ml} / \mathrm{g}$. The average initial granule diameter was around $1.54 \pm 0.29 \mathrm{~mm}$ and most of the granules ranged between 1.0-2.0 $\mathrm{mm}$. The dominant algae genus in the seeded granules was determined to be Leptolyngbya, occupying about $78-80 \%$ of the algae biomass (data not shown).

Synthetic wastewater was used in this study and prepared with sodium acetate as the sole carbon source in the experiments. As illustrated in Table 1, a stepwise decrease in influent $\mathrm{COD} / \mathrm{N}$ ratio was applied to $\mathrm{R}_{2}$ with less addition of sodium acetate (while keeping at a constant $\mathrm{N}$ concentration) during the operation. Its influent $\mathrm{COD} / \mathrm{N}$ ratio varied from 8 to 4,2 , and 1 , respectively when the influent COD concentration decreased from 400 to $50 \mathrm{mg} / \mathrm{L}$ during the four experimental stages (I, II, III, and IV). Other nutrients were added into the influent at the same levels throughout the experiments, including $50 \mathrm{mg} \mathrm{NH}_{4}{ }^{+}-\mathrm{N} / \mathrm{L}\left(\mathrm{NH}_{4} \mathrm{Cl}\right), 10 \mathrm{mg} \mathrm{PO}_{4}{ }^{3-}-\mathrm{P} / \mathrm{L}\left(\mathrm{KH}_{2} \mathrm{PO}_{4}\right), 10 \mathrm{mg} \mathrm{Ca}{ }^{2+} / \mathrm{L}\left(\mathrm{CaCl}_{2}\right)$, $5 \mathrm{mg} \mathrm{Mg}{ }^{2+} / \mathrm{L}\left(\mathrm{MgSO}_{4} \cdot 7 \mathrm{H}_{2} \mathrm{O}\right), 5 \mathrm{mg} \mathrm{Fe}{ }^{2+} / \mathrm{L}\left(\mathrm{FeSO}_{4} \cdot 7 \mathrm{H}_{2} \mathrm{O}\right)$, and $1 \mathrm{ml} / \mathrm{L}$ of trace elements solution. The composition of the trace elements solution was prepared according to Huang et al. (2015b). The influent $\mathrm{pH}$ was adjusted to $7.5-7.7$ by adding $300 \mathrm{mg} / \mathrm{L}$ of $\mathrm{NaHCO}_{3}$ in the influent.

\section{Table 1}




\subsection{Experimental set-up and operation conditions}

Two identical cylindrical SBRs $\left(\mathrm{R}_{1}\right.$ and $\left.\mathrm{R}_{2}\right)$ made of acrylic plastic were used in this study. Their dimension was $54 \mathrm{~mm}$ in diameter, $3 \mathrm{~mm}$ in wall thickness and $500 \mathrm{~mm}$ in height with a total volume of $1.14 \mathrm{~L}$ and a working volume of $0.92 \mathrm{~L}$ each. Restated, they were operated in parallel under the same conditions except the difference in influent $\mathrm{COD} / \mathrm{N}$ ratio: $\mathrm{R}_{1}$ was used as the control with no change in its influent $\mathrm{COD} / \mathrm{N}$ ratio $(=8)$, and $\mathrm{R}_{2}$ was operated with the change in the influent $\mathrm{COD} / \mathrm{N}$ ratio according to Table 1. $\mathrm{R}_{1}$ and $\mathrm{R}_{2}$ were operated under the illumination of two artificial solar lights fixed at $12 \mathrm{~h} /$ $12 \mathrm{~h}$ (day/night). The light was located on the top of the reactor with light illuminance of approximately $7200 \mathrm{~lx}$ on the surface of water in the reactor. A black plastic bag was used to cover the light together with the reactors to prevent their additional exposure to the room light.

The two reactors were operated at room temperature $\left(25 \pm 2{ }^{\circ} \mathrm{C}\right)$ for 90 days under alternatively anaerobic and aerobic conditions with each cycle of $4 \mathrm{~h}$. Each cycle consisted of 2 min filling, $60 \mathrm{~min}$ non-aeration period, $173 \mathrm{~min}$ aeration period, $2 \mathrm{~min}$ settling, and 3 min effluent discharge. During aeration, air was provided by an air pump (AK-40, KOSHIN, Japan) from the bottom of reactor through air bubble diffusers at an air flow rate of $0.55 \mathrm{~cm} / \mathrm{s}$. All these operations were performed automatically by the timer-controlled pumps. The volumetric exchange ratio was kept at 53\%, resulting in a hydraulic retention time (HRT) of about $7.5 \mathrm{~h}$. Sludge retention time (SRT) was kept at approximately 30 days through controlled sludge discharge. 


\subsection{Analytical methods}

Water samples were collected once every 2 days, and the sampling was done at the end of operation cycle during daytime $(17: 00 \mathrm{pm})$. After filtration through $0.22 \mu \mathrm{m}$ membrane, the filtrates were used for analysis. The determinations of mixed liquor (volatile) suspended solids (ML(V)SS), SVI, total nitrogen (TN), ammonia nitrogen $\left(\mathrm{NH}_{4}{ }^{+}-\mathrm{N}\right)$, nitrite nitrogen $\left(\mathrm{NO}_{2}{ }^{-}-\mathrm{N}\right)$, nitrate nitrogen $\left(\mathrm{NO}_{3}{ }^{-}-\mathrm{N}\right)$, and phosphorus $\left(\mathrm{PO}_{4}{ }^{3-}-\mathrm{P}\right)$ were conducted according to the standard methods (APHA, 2012). Dissolved organic carbon (DOC), dissolved inorganic carbon (DIC), and dissolved total carbon (DTC) were

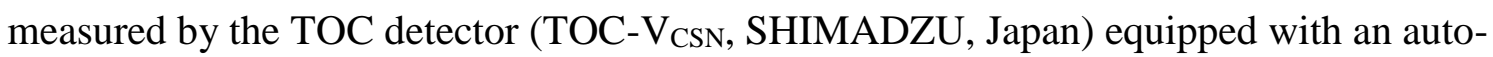
sampler (ASI-V, SHIMADZU, Japan). $\mathrm{pH}$ was determined by a compact $\mathrm{pH}$ meter (Horiba, Japan). Dissolved oxygen (DO) concentration in the bulk liquor was measured with a DO meter (DO-31P, DKK-TOA, Japan). The extraction and determination of chlorophyll $a$ from granules were conducted using acetone and a spectrophotometry method described by Tang et al. (2016).

Granular size was measured by a stereo microscope (STZ-40TBa, SHIMADZU, Japan) with a program Motic Images Plus 2.3S (version 2.3.0). Morphological characteristics of the granules were observed using Leica M205 C Microscope (Leica Microsystems, Switzerland) and scanning electron microscope (JSM6330f, Japan). The settling velocity was determined by placing individual granules in a graduated cylinder filled with tap water and measuring the time it took to drop from a fixed height. At least 100 granules were sampled randomly for a single test, and the average values were used in this study. The strength of granules was expressed in terms of integrity coefficient (\%) 
by a shock method as described by Ghangrekar et al. (2005), which was defined as the ratio of solids in the supernatant after being shaken on a platform shaker at $200 \mathrm{rpm}$ for $5 \mathrm{~min}$ to the total weight of the granular sludge used for this test.

$\mathrm{P}$ in granules, namely total phosphorus (TP), organic phosphorus (OP), inorganic phosphorus (IP), non-apatite phosphorus (NAIP) and apatite phosphorus (AP), was fractioned and quantified using the Standards, Measurements and Testing (SMT) Programme extraction protocol (Ruban et al., 1999). The concentration of metal ions in the granules was determined by ICP-AES (ICPS-8100, SHIMADZU, Japan) after the sludge samples being digested with $\mathrm{HNO}_{3}$ and $\mathrm{H}_{2} \mathrm{O}_{2}$ according to the method proposed by US EPA (Arsenic and Beryllium, 1996). Organic C, H and N contents in the sludge were determined by a CHN Elemental Analyzer (Perkin-Elmer 2400 II, USA).

Loosely bound EPS (LB-EPS) was extracted using the method described by Miao et al. (2016) with slight modifications. Briefly, $5 \mathrm{ml}$ sample was centrifuged at $5000 \mathrm{~g}$ for $15 \mathrm{~min}$. The supernatant was filtered through $0.22 \mu \mathrm{m}$ membrane, and the filtrate was collected to represent the LB-EPS fraction. Tightly bound EPS (TB-EPS) extraction procedure was carried out according to the method described by Adav and Lee (2008) with some modifications. After the supernatant being discarded for the measurement of LB-EPS, the residual sludge was resuspended with $0.9 \%(\mathrm{w} / \mathrm{v}) \mathrm{NaCl}$ to the original volume, and then heated to $80{ }^{\circ} \mathrm{C}$ and kept at this temperature for $30 \mathrm{~min}$. The extracted solution was centrifuged at $10000 \mathrm{~g}$ for 20 min under $4{ }^{\circ} \mathrm{C}$, then the supernatant was filtrated through $0.22 \mu \mathrm{m}$ membrane and the collected filtrate was used for analysis of the TB-EPS fraction. The EPS samples (both LB- and TB-EPS) were stored at $-30{ }^{\circ} \mathrm{C}$ prior 
to analysis. Extracellular polysaccharides (PS) and proteins (PN) in the extracted EPS were measured by using the phenol-sulfuric acid method and the Lowry-Folin method, respectively (Li et al., 2014).

Microbial activity was indicated by specific oxygen uptake rate (SOUR) in this study. The measurement of SOUR was conducted in duplicate for granules from both SBRs at each operation stage. A $25 \mathrm{~mL}$ granule sample, taken from each SBR at the end of aeration phase, was washed with deionized water for 3 times, and then mixed with 125 $\mathrm{mL}$ synthetic wastewater after being loaded into a $250 \mathrm{~mL}$ glass flask. Prior to the test, air was pumped into the flask till the DO increased to a relatively stable level. The DO level in the mixture was continuously recorded by the DO meter right from the moment when the aeration was stopped and at the same time the flask was sealed (leaving the DO meter inside). The SOUR value ( $\left.\mathrm{mg} \mathrm{O}_{2} / \mathrm{g}-\mathrm{MLVSS} \cdot \mathrm{h}\right)$ was calculated from the DO reduction slope (along with the time after stopping aeration) and the concentration of MLVSS (Tang et al., 2016). Specific ammonia uptake rate (SAUR) and specific nitrite uptake rate (SNUR) were measured according to Huang et al. (2015a).

\section{Results and discussion}

\subsection{Characteristics of algal-bacterial AGS during 90 days' operation}

\subsubsection{Granular morphology}

In this study, mature algal-bacterial granules instead of activated sludge were used as seed sludge due to the expected shorter start-up time. The morphological changes of 
granules in $\mathrm{R}_{1}$ and $\mathrm{R}_{2}$ were observed and recorded during the experiment. Initially, the mature granules were green in most parts of the granules, which reflected an irregular shape, compact and dense structure. After day 30, almost all the granules in $\mathrm{R}_{1}$ and $\mathrm{R}_{2}$ turned into dark green till the end of experiment, probably due to some changes of algal species exposed to lower light illuminance as the quantify and size of granules increased. On day 90, the granules in the two reactors kept their compact and dense structure, and the granules in $\mathrm{R}_{2}$ were relatively smaller compared to those in $\mathrm{R}_{1}$. Also, seen from their SEM images, not so much change was observed in the morphology of bacteria accumulated onto the surface of granules from the two reactors.

\subsubsection{Granule growth and its size distribution}

The changes in granular size and its distribution in $R_{1}$ and $R_{2}$ are shown in Fig. 1. At the beginning, the granules were mainly within 1.0-1.5 and 1.5-2.0 $\mathrm{mm}$, occupying about $46 \%$ and $46 \%$ of the total granules in both reactors, respectively. After 90 days' operation, larger particles dominated in both reactors, but the granular size distribution was obviously different between the granules from these two reactors. The granules ranging within $2.0-2.5 \mathrm{~mm}$ and $>2.5 \mathrm{~mm}$ accounted for $29 \%$ and $63 \%$ in $\mathrm{R}_{1}$, respectively. In contrast, the granules of $2.0-2.5 \mathrm{~mm}$ gradually became the dominant portion in $\mathrm{R}_{2}$ (about $48 \%$ on day 90). Fig. 1 also shows the average diameter of granules in the two reactors. On day 90, the average granular size in both reactors was averagely increased from the initial $1.54 \pm 0.29$ to $2.62 \pm 0.53 \mathrm{~mm}\left(\mathrm{R}_{1}\right)$ and $2.33 \pm 0.51 \mathrm{~mm}\left(\mathrm{R}_{2}\right)$, respectively. This phenomenon is mainly attributable to the difference in organic loading 
to these two reactors. As stated, a higher COD loading would generally result in bigger granules with a compact structure (Liu et al. 2003). Results from this work show that the decrease in influent $\mathrm{COD} / \mathrm{N}$ ratio exerted some influence on the granular size and its distribution as well.

\section{Fig. 1}

\subsubsection{Biomass increase, sludge settleability and granular stability}

Fig. 2a demonstrates the changes in MLSS and MLVSS/MLSS ratio of granules in the two reactors. The initial algal-bacterial AGS MLSS was $5.25 \mathrm{~g} / \mathrm{L}$ in $\mathrm{R}_{1}$ and $5.30 \mathrm{~g} / \mathrm{L}$ in $\mathrm{R}_{2}$ with the same MLVSS/MLSS ratio of 0.78 . From day 21 (Stage II) on, the MLSS in $\mathrm{R}_{2}$ dropped sharply, and finally tended to be stable during Stage IV, which was basically maintained around $3.21 \mathrm{~g} / \mathrm{L}$. This phenomenon, i.e. a lower biomass growth in $\mathrm{R}_{2}$, was probably attributable to the decrease in influent COD concentration from 400 to $50 \mathrm{mg} / \mathrm{L}$. In contrast, the biomass in $\mathrm{R}_{1}$ kept fluctuating at 5.92-7.63 g/L from day 28 to day 90 , with the MLVSS/MLSS ratio of 0.76-0.79 during the experiment. While in $\mathrm{R}_{2}$, the MLVSS/MLSS ratio of the granules fluctuated between 0.75-0.79 before Stage III, which was slightly decreased to $0.70-0.72$ during Stage IV (at influent COD/N ratio=1). This observation indicates that the growth of biomass in the algal-bacterial granular system is dependent on the influent organics or carbonaceous substances to some extent, while this system can also quickly adapt to the low carbon environment like $\mathrm{COD} / \mathrm{N}=1$. On the other hand, a relatively low MLVSS/MLSS ratio for the granules in $\mathrm{R}_{2}$ during Stage IV 
(COD/N=1, Fig. 2a) might imply that more mineral substances (especially Fe) were accumulated into the granules under this operation condition (Oehmen et al., 2007).

\section{Fig. 2}

SVI and settling velocity can be used to indicate the settleability of granular sludge. Fig. $2 \mathrm{~b}$ shows the changes in $\mathrm{SVI}_{5}$ and settling velocity of the granules from the two reactors. The granular $\mathrm{SVI}_{5}$ values were determined to vary between $33.1-47.7 \mathrm{ml} / \mathrm{g}$ MLSS in $\mathrm{R}_{1}$, signaling the good settleability of algal-bacterial granules during the longterm operation. This observation is in accordance with the results from Ni et al. (2009) who found that $\mathrm{SVI}_{10}$ and $\mathrm{SVI}_{30}$ values were stably below $50 \mathrm{ml} / \mathrm{g}-\mathrm{MLSS}$ when feeding low-strength municipal wastewater into AGS reactors. In $\mathrm{R}_{2}$, the $\mathrm{SVI}_{5}$ fluctuated between 34.2-44.7 $\mathrm{ml} / \mathrm{g}-$ MLSS till day 70 and increased to 61.5 and $58.1 \mathrm{ml} / \mathrm{g}-\mathrm{MLSS}$ on day 84 and day 90, respectively. A much lower MLSS concentration in $\mathrm{R}_{2}$ during Stage IV (Fig. 2a) to some extent contributed to the increase in $\mathrm{SVI}_{5}$ of its granules. For the granular sludge in $R_{1}$ and $R_{2}$, the settling velocity was detected to averagely decrease from the initial 32.0 to 27.6 and $15.0 \mathrm{~m} / \mathrm{h}$ respectively at the end of operation. The above results show that the low carbon influent might limit the growth of fast-settling bacteria in the algal-bacterial AGS, possibly resulting in the much lower MLVSS or MLSS concentration in $\mathrm{R}_{2}$, especially during Stages III and IV. In addition, some filamentous bacteria were observed to grow in the two reactors till the end of experiment, which seemed to have some negative effect on the settleability of algal-bacterial AGS.

In this study, granular stability was expressed in terms of integrity coefficient, and a lower value denotes a better stability (Muda et al., 2010). As shown in Fig. 2c, the 
integrity coefficient of the granules in $\mathrm{R}_{1}$ was between $0.9-2.2 \%$ during the 90 days' operation, signaling the excellent stability of algal-bacterial AGS. However, the integrity coefficient of the granules in $\mathrm{R}_{2}$ increased from 0.7 to $5.4 \%$ when the influent $\mathrm{COD} / \mathrm{N}$ ratio decreased from 8 to 1 , implying that the low carbon influent $(\mathrm{COD} / \mathrm{N}=4,2$ and 1$)$ exerted some negative effect on the stability of granules. However, according to Ghangrekar et al. (2005), granules with integrity coefficient of less than $20 \%$ were considered as high-strength granules. Therefore, it is worthwhile to note that the algalbacterial AGS possesses excellent granular stability and integrity, even being applied to treat low carbon wastewater $(\mathrm{COD} / \mathrm{N}=1)$. In addition, the whole system could quickly adjust and positively respond to the decrease in influent carbon concentration. This observation is different from Luo et al. (2014) and Kocaturk and Erguder (2016) who noticed the occurrence of aerobic granule disintegration when the influent $\mathrm{COD} / \mathrm{N}$ ratio decreased to 1, which might be associated with the different influent characteristics and co-existing algae in the algal-bacterial AGS system in this study.

\subsection{Reactor performance}

\subsubsection{Carbon removal}

The changes in effluent DOC concentration and removal efficiency in $R_{1}$ and $R_{2}$ are shown in Fig. 3a. During the whole experimental period, the DOC removal efficiency was averagely $96 \%$ in $R_{1}$ with effluent DOC being always $<11 \mathrm{mg} / \mathrm{L}$, signaling the excellent organics removal of the algal-bacterial AGS system. When the influent COD was decreased to $200 \mathrm{mg} / \mathrm{L}(\mathrm{COD} / \mathrm{N}=4)$ from day 20 on, interestingly, little difference in 
DOC removal efficiency was noticed in $\mathrm{R}_{2}$, around $95-96 \%$; while some decrease in DOC removal efficiency was discerned, averagely 90.6 or $82.5 \%$ when the influent COD concentration was further decreased to 100 or $50 \mathrm{mg} / \mathrm{L}(\mathrm{COD} / \mathrm{N}=2$ or 1$)$ as scheduled. However, importantly, in comparison to the effluent from $\mathrm{R}_{1}$ (averagely $6 \mathrm{mg} / \mathrm{L}$ ), a lower DOC concentration (averagely $4 \mathrm{mg} / \mathrm{L}$ ) was always detected in the effluent from $\mathrm{R}_{2}$ throughout the whole experiment. This observation indicates that the algal-bacterial AGS system can be used to treat varying strength of organic wastewater.

Fig. $3 b$ presents the changes in DTC and DIC concentrations in the effluents from the two reactors during the operation. Compared with the relatively stable DIC concentration ( $45-55 \mathrm{mg} / \mathrm{L}$ ) in the effluent from $\mathrm{R}_{1}$, the DIC concentration in the effluent from $R_{2}$ was significantly decreased from averagely 52 to 10,2 , and $1 \mathrm{mg} / \mathrm{L}$ when the influent COD concentration was adjusted from 400 to 200,100 , and $50 \mathrm{mg} / \mathrm{L}$, respectively. This phenomenon may be attributable to the growth of algae who were responsible for the enhanced DIC uptake since much more increase in chlorophyll $a$ concentration was detected in the granules from $\mathrm{R}_{2}$ along with the operation by feeding low $\mathrm{COD} / \mathrm{N}$ ratio wastewater. This observation also implies that the algal-bacterial AGS system could be very promising for reduction in greenhouse gases (GHGs) emission from wastewater treatment. Further research is necessary for optimization of the operation conditions and quantification of GHGs emission reduction.

\section{Fig. 3}

\subsubsection{Nitrogen and phosphorus removal}


In order to investigate the effect of influent $\mathrm{COD} / \mathrm{N}$ ratio on nitrification in the algalbacterial AGS system, $\mathrm{N}$ species including $\mathrm{NH}_{4}{ }^{+}-\mathrm{N}, \mathrm{NO}_{2}{ }^{-}-\mathrm{N}$, and $\mathrm{NO}_{3}^{-}-\mathrm{N}$ were monitored in the two reactors when the stepwise decrease in influent COD from 400 to $50 \mathrm{mg} / \mathrm{L}$ was applied to $\mathrm{R}_{2}$. The changes in $\mathrm{N}$ concentrations in the effluents from both reactors are shown in Fig. 4a. Correspondingly, their nitritation and nitratation efficiencies calculated according to Li et al. (2015) are depicted in Fig. 4b. It is clearly that the two reactors exhibited excellent nitratation efficiency (97-100\%). That is, in both systems $\mathrm{NO}_{2}^{-}-\mathrm{N}$ can be easily converted into $\mathrm{NO}_{3}-\mathrm{N}$ under the designed operation conditions. In addition, little $\mathrm{NO}_{2}{ }^{-}-\mathrm{N}$ (less than $1.4 \mathrm{mg} / \mathrm{L}$ ) was detected in the effluents from both reactors till the end of experiment. These results imply that the decrease in influent $\mathrm{COD} / \mathrm{N}$ ratio from 8 to 1 seems to have little influence on nitratation process of the algal-bacterial AGS system. When the influent COD/N ratio decreased to 2 in $\mathrm{R}_{2}$ during Stage III, however, a clear difference was noticed in nitritation efficiency between $\mathrm{R}_{1}$ and $\mathrm{R}_{2}$ : higher effluent $\mathrm{NH}_{4}{ }^{+}-\mathrm{N}$ concentrations and thus lower nitritation efficiency were detected in $\mathrm{R}_{2}$ (averagely $5.7 \mathrm{mg} / \mathrm{L}$ and $88 \%)$ than $\mathrm{R}_{1}(\sim 0 \mathrm{mg} / \mathrm{L}$ and $100 \%)$. The effluent $\mathrm{NH}_{4}{ }^{+}-\mathrm{N}$ concentration from $\mathrm{R}_{2}$ increased sharply from day 65 (Stage IV, COD/N=1), and the nitritation efficiency dropped promptly to lower than 70\% (averagely 69\%). On the other hand, simultaneous denitrification occurred during the whole operation, which was greater at higher influent $\mathrm{COD} / \mathrm{N}$ ratio conditions according to the $\mathrm{NO}_{3}^{-}-\mathrm{N}$ and $\mathrm{TN}$ removal results (Figs. 4a and c). Therefore, it can be inferred that lower influent COD/N ratio $(4,2$ and 1$)$ might negatively impact the nitritation and denitrification processes in the algal-bacterial AGS system. The SOUR, SNUR, and SAUR of the granules from $\mathrm{R}_{1}$ and $\mathrm{R}_{2}$ were also measured. The granules from $\mathrm{R} 1$ exhibited almost similar or slightly 
enhanced bioactivities in terms of SOUR, SAUR and SNUR during the whole experiment. The SOUR of granules from $\mathrm{R}_{2}$, however, decreased from 24.5 to $9.1 \mathrm{mg}$ $\mathrm{O}_{2} / \mathrm{g}-\mathrm{MLVSS} \cdot \mathrm{h}$ when the influent COD/N ratio was decreased from 8 to 1 . On the other hand, the SAUR of granules from $\mathrm{R}_{2}$ gradually decreased from 6.03 to $3.42 \mathrm{mg} \mathrm{N} / \mathrm{g}$ MLVSS $\mathrm{h}$ along with the operation; while little change in SNUR was detected in the granules from $\mathrm{R}_{2}$ during the test period. The changes in granular SAUR and SNUR are in accordance with the variations in the effluent $\mathrm{N}$ concentrations detected and the two reactors' nitritation and nitratation efficiencies (Figs. 4a and b). Two reasons might be contributed to the lower SOUR and SAUR of granules from $\mathrm{R}_{2}$ : (1) The ammoniaoxidizing bacteria and heterotrophic bacteria in the algal-bacterial AGS may have lower microbial activities; and (2) the ammonia uptake by algae might be inhibited when feeding low $\mathrm{COD} / \mathrm{N}$ ratio wastewaters. In the meantime, the sharp decrease in $\mathrm{TN}$ removal capacity in $\mathrm{R}_{2}$ (Fig. 4c) implies that denitrification by heterotrophic bacteria contributed more to the TN removal in the algal-bacterial AGS system compared to the $\mathrm{N}$ assimilation by the grown algae that increased remarkably under the tested conditions. The detailed mechanisms still need further investigation.

\section{Fig. 4}

Fig. $4 \mathrm{c}$ also shows the average TP removal capacity during the 90 days' operation. The two reactors exhibited almost a similar variation trend during the whole operation, ranging between 1.9-5.5 $\mathrm{mg} / \mathrm{g}-\mathrm{MLVSS} \cdot \mathrm{d}\left(\mathrm{R}_{1}\right)$ and $1.9-5.4 \mathrm{mg} / \mathrm{g}-\mathrm{MLVSS} \cdot \mathrm{d}\left(\mathrm{R}_{2}\right)$, respectively. This observation might be attributable to the application of the same SRT (30 days) to control both reactors. A slightly higher average TP removal capacity was 
detected in the granules from $R_{1}$ (averagely $4.1 \mathrm{mg} / \mathrm{g}-\mathrm{MLVSS} \cdot \mathrm{d}$ ) than those from $\mathrm{R}_{2}(3.6$ $\mathrm{mg} / \mathrm{g}-\mathrm{MLVSS} \cdot \mathrm{d}$ ), possibly owing to the difference in biomass concentrations in the two reactors (section 3.1.3). However, at the end of the experiment, the TP removal capacity was almost same in both reactors $(\sim 3.5 \mathrm{mg} / \mathrm{g}-\mathrm{MLVSS} \cdot \mathrm{d})$, indicating that influent COD/N ratio might have little influence on TP removal capacity in the algal-bacterial AGS system, which is probably controlled by SRT. On the other hand, during the operation the anaerobic $\mathrm{P}$ release and aerobic $\mathrm{P}$ uptake rates were also determined in the two SBRs on days $10,30,55$, and 85 , respectively. As shown, the average anaerobic P release and aerobic $\mathrm{P}$ uptake in $\mathrm{R}_{2}$ decreased from the 6.07 and $2.33 \mathrm{mg} / \mathrm{g}-\mathrm{MLVSS} \cdot \mathrm{h}$ on day 10 to 0.21 and $0.09 \mathrm{mg} / \mathrm{g}-\mathrm{MLVSS} \cdot \mathrm{h}$ on day 85 , suggesting the growth or activity of polyphosphate-accumulating organisms (PAOs) in $\mathrm{R}_{2}$ might be inhibited under low influent $\mathrm{COD} / \mathrm{N}$ ratio conditions. This observation may contribute to the slight decrease in $\mathrm{P}$ removal capacity in $\mathrm{R}_{2}$ (Fig. 4c) to some extent. As it is known, $\mathrm{P}$ can be removed from wastewater through both biotic $\mathrm{P}$ assimilation into the biomass and abiotic $\mathrm{P}$ precipitation (de Godos et al., 2009). In case of the algal-bacteria AGS system in this study, most probably co-precipitation of phosphate with other co-existing metals (Huang et al., 2015b) and algae assimilation were the major contributors to the relatively stable $\mathrm{P}$ removal (Fig. 4 c) in $\mathrm{R}_{2}$ under the low influent COD/N ratio conditions. Since only $1-15 \%$ of the anaerobic bacterial P release and aerobic bacterial P uptake (typically for PAOs) rates were detected in the granules from $\mathrm{R}_{2}$, optimization of the operation conditions or strategies is crucial for enhanced P removal and accumulation by using this algalbacterial AGS system. 


\subsection{Variation in nutrients content in the granules during the operation}

The TP content analysis and P fractionation in the granules from the two reactors were performed during the operation by using SMT method (Fig. 5a). In general, The TP content in the granules reflected a similar trend in the two reactors and reached to 30.8 and $30.6 \mathrm{mg} / \mathrm{g}-\mathrm{MLSS}$ from $\mathrm{R}_{1}$ and $\mathrm{R}_{2}$, respectively on day 14 (Stage I). Specifically, during the operation of Stage II and Stage III (from day 28 to day 70, the influent COD/N ratio $=4$ and 2 , respectively), the TP content in the granules from $R_{2}$ was always a little bit lower than that from $\mathrm{R}_{1}$, which then increased faster and thereafter higher than that from $\mathrm{R}_{1}$ after day 84 (influent $\mathrm{COD} / \mathrm{N}=1$ ). This observation is possibly associated with the $\mathrm{P}$ assimilation potential of algae which grew faster during Stage IV, as much higher amount of chlorophyll $a$ in the granules from $\mathrm{R}_{2}(13.0 \mathrm{mg}$ Chla/g-MLVSS on day 84 ) was detected compared with that from $\mathrm{R}_{1}$ (6.2 mg Chla/g-MLVSS on day 84). On day 90, averagely 26.7 and $28.3 \mathrm{mg} / \mathrm{g}$-MLSS of TP were respectively detected in the granules from $R_{1}$ and $R_{2}$. Future research work is still necessary for detailed information about the influence of algae growth on the $\mathrm{P}$ accumulation during the long-term operation of the algal-bacterial AGS system and its optimization.

\section{Fig. 5}

Fig. 5a also shows the changes in P fractionation (OP, IP (NAIP and AP)) during the operation. As seen, IP was the dominant P fraction in the seeded algal-bacterial AGS, occupying $76 \%$ and $75 \%$ of $\mathrm{TP}$ in the granules from $\mathrm{R}_{1}$ and $\mathrm{R}_{2}$, respectively. Both granules contained NAIP about $70 \%$ of TP. Besides, the NAIP content slightly decreased to 19.0 and $17.3 \mathrm{mg} / \mathrm{g}-\mathrm{MLSS}$, accounting for $75 \%$ and $62 \%$ of TP respectively in the 
granules from $R_{1}$ and $R_{2}$ on day 90 . Interestingly, the $\mathrm{OP}$ content in the granules from $\mathrm{R}_{1}$ decreased gradually till the end of experiment, about $4.5 \mathrm{mg} / \mathrm{g}-\mathrm{MLSS}$ on day 90 . In contrast, the OP content in the granules from $\mathrm{R}_{2}$ gently varied between $5.5-6.7 \mathrm{mg} / \mathrm{g}$ MLSS during Stage II and Stage III (from day 28 to day 70), which significantly increased to 8.1 and $10.1 \mathrm{mg} / \mathrm{g}-$ MLSS on day 84 and day 90, respectively. Most importantly, AP, the $\mathrm{P}$ form directly associated with $\mathrm{Ca}$, was very low in the seeded granules, occupying only 5-6\% of TP. Along with the operation from Stage II to Stage IV (day 28 to day 90), the AP content in the granules from $\mathrm{R}_{2}$ decreased from $1.7 \mathrm{mg} / \mathrm{g}$ MLSS (6\% of TP) to $0.6 \mathrm{mg} / \mathrm{g}$-MLSS ( $2 \%$ of TP), while it kept stable for the granules in $\mathrm{R}_{1}$ (about $7 \%$ of TP on day 28 and day 90 ).

In addition, NAIP and OP can be used to indicate the potentially releasable and bioavailable P fractions (Pardo et al., 2003; Xie et al., 2011). The P bioavailability $((\mathrm{NAIP}+\mathrm{OP}) / \mathrm{TP})$ varied slightly from the initial $95 \%$ to $92 \%$ in the granules of $\mathrm{R}_{1}$, which increased from initial $94 \%$ to $98 \%$ in the granules from $\mathrm{R}_{2}$ after 90 days' operation. As reported, the proportion of (NAIP + OP) to TP was about $80 \%$ for activated sludge and general AGS (Huang et al., 2015b). Results from this study indicate that the algal-bacterial AGS possesses high potential for P recovery from wastewater, resulting in P-rich granules with high P mobility and bioavailability. Moreover, much higher P bioavailability in granules was achieved in this study when the influent $\mathrm{COD} / \mathrm{N}$ ratio decreased to 1 , suggesting some promotion mechanism of bioavailable $\mathrm{P}$ accumulation was stimulated under the extremely low carbon condition. This observation also indicates the great potential of using algal-bacterial AGS to recover P from wastewater, especially 
under low carbon conditions, and the resultant P-rich granules can be easily used for multiple purposes.

The TN content in the granules from the two reactors was also monitored during the whole operation (Fig. 5b). As a result, little difference in TN content was detected in the granules from $\mathrm{R}_{1}$ and $\mathrm{R}_{2}$ during Stage I and Stage II, varying between 90-93 mg/g-MLSS. And a slight increase in TN content was detected in the granules from $\mathrm{R}_{1}$, about $95 \mathrm{mg} / \mathrm{g}$ MLSS at the end of experiment. However, from Stage III to Stage IV (day 42 to day 90), the $\mathrm{TN}$ content in the granules from $\mathrm{R}_{2}$ remarkably decreased, about $70 \mathrm{mg} / \mathrm{g}-\mathrm{MLSS}$ on day 90. Taking the increased effluent $\mathrm{NH}_{4}{ }^{+}-\mathrm{N}$ concentration (Fig. 4a) together with the variation in TN content in the granules (Fig. 5b) from $\mathrm{R}_{2}$, it is speculated that some nitrogenous organics stored or entrapped in the granule matrix might be utilized as carbon source by heterotrophic microbes under the lower influent $\mathrm{COD} / \mathrm{N}$ ratio conditions. If it happens, these organics might be decomposed into $\mathrm{NH}_{4}{ }^{+}$, to some extent resulting in the increase of effluent $\mathrm{NH}_{4}{ }^{+}-\mathrm{N}$ concentration. The real reason for the decreased $\mathrm{TN}$ removal at extreme low influent $\mathrm{COD} / \mathrm{N}$ needs further detailed investigation.

\subsection{Characteristic change of EPS content and its relationship with granular stability}

EPS, mainly polysaccharides (PS) and proteins (PN), are secreted products from the cells. The EPS content is usually associated with the granular structure (Caudan et al., 2014), granule formation and microbial activity as well (Guo et al., 2016). EPS can be mainly divided into two different fractions, i.e. LB-EPS and TB-EPS (Li and Yang, 
2007). In this study, the total EPS content was the sum of the two major components, PS and PN (Fig. 6).

\section{Fig. 6}

The changes in PN, PS and the total EPS during the operation are shown in Fig. 6a. Clearly, the total EPS content in the granules from $\mathrm{R}_{1}$ kept increasing till the end of experiment, from the initial 196.2 to $272.8 \mathrm{mg} / \mathrm{g}$-MLVSS on day 90 . However, for $\mathrm{R}_{2}$, the EPS content in the granules was detected to increase in an almost same trend as that in $\mathrm{R}_{1}$ before day 42 (the beginning of Stage III when the influent COD/N ratio was decreased from 4 to 2), then sharply and further decreased to about $114.5 \mathrm{mg} / \mathrm{g}-\mathrm{MLVSS}$ on day 84 . On day 90, it was slightly recovered to $122.6 \mathrm{mg} / \mathrm{g}$-MLVSS. More specifically, the PS content in the granules increased gradually from the initial $18.0 \mathrm{mg} / \mathrm{g}-\mathrm{MLVSS}$ to 39.1 and $51.9 \mathrm{mg} / \mathrm{g}-\mathrm{MLVSS}$ on day 90 in $\mathrm{R}_{1}$ and $\mathrm{R}_{2}$, respectively, in which the granules from $\mathrm{R}_{2}$ always had a higher PS content from the beginning of deceasing the influent $\mathrm{COD} / \mathrm{N}$ ratio. On the other hand, when the influent $\mathrm{COD} / \mathrm{N}$ ratio was decreased to 2 or 1 , a remarkable reduction in PN content was noticed in the granules from $\mathrm{R}_{2}$. Liu and Tay (2002) and Beun et al. (2002) pointed out that the typical range of PN/PS ratio in the aerobic granules was $0.1-5$. In this study, although the PN/PS ratios in the granules from both reactors obviously decreased due to the reduction of PN content or increase in PS content in granules, the PN/PS values were still within the reported range of previous researches, possibly due to the strong and stable structure of the algal-bacterial AGS.

The changes of LB-EPS and TB-EPS contents with their major components (PN and PS) during the 90 days' operation are illustrated in Fig. $6 \mathrm{~b}$ and c, respectively. The trends 
in TB-EPS and their components in the granules from both reactors were quite similar with those of the total EPS in the granules (Fig. 6a). The LB-EPS in the granules, however, showed a gradual increase trend for both reactors during the whole operation, in which the granules from $\mathrm{R}_{2}$ contained much higher LB-EPS after the influent COD/N ratio was further decreased to 2 or 1 . While a similar decline trend was detected in the PN/PS ratio of LB-EPS, and more specifically, not so much difference was found in the PN/PS ratio of LB-EPS in the granules from the two reactors during the operation of Stage IV. As seen from section 3.1.3, the granules in the two reactors exhibited good stability during the whole operation, even for $\mathrm{R}_{2}$ to which the influent $\mathrm{COD} / \mathrm{N}$ ratio was decreased from 8 to 1 resulting in remarkable decrease in its granular TB-EPS content (Fig. 6c). Therefore, LB-EPS is probably the key factor to control the deterioration of granular stability in the algal-bacterial AGS system (Zhang et al., 2016b).

\subsection{Implication of this study}

Results show that the algal-bacterial AGS system can well maintain its granular stability and stable operation when treating low carbon wastewaters. More importantly, when the influent COD concentration decreased to $50 \mathrm{mg} / \mathrm{L}(\mathrm{COD} / \mathrm{N}=1)$, the algalbacterial AGS with compact and dense structure could still exhibit good granular stability. As a result, the algal-bacterial AGS system is more prospective due to its low requirement for external carbon source and reduced GHGs emission during wastewater treatment. On the other hand, the obtained biomass, or the algal-bacterial granules with high $\mathrm{P}$ and $\mathrm{N}$ contents, can be easily developed as functional materials for multiple 
purposes. In addition, the granules with high bioavailable $\mathrm{P}$ up to $98 \%$ can also be used for efficient P recovery. This work indicates that algal-bacterial AGS system is promising for the treatment of low carbon wastewaters, not only due to its low external carbon source requirement and reduced GHGs emission to some content, but also due to its great potential for production of $\mathrm{P} / \mathrm{N}$-rich granular biomass during wastewater treatment.

However, as mentioned before, future research is necessary to optimize the operation conditions for enhanced $\mathrm{P}$ accumulation in the granules and to quantify the reduction of GHGs emission. Besides, close attention should also be paid to the decreased $\mathrm{N}$ uptake and denitrification when feeding extreme low carbon wastewaters. The changes in microbial biodiversity in the granules from the two reactors are undergoing, which is expected to shed light on the mechanisms involved and the contribution of algae and bacteria to the stable operation of the algal-bacterial AGS system.

\section{Conclusions}

Algal-bacterial AGS kept granular stability with compact structure when coping with varying strength of organic wastewater, even at low $\mathrm{COD} / \mathrm{N}$ ratio like $\mathrm{COD} / \mathrm{N}=1$, in which LB-EPS might be the key to its structural stability. This novel system also exhibited great potential for reducing GHGs emission. The high $\mathrm{P}$ and $\mathrm{N}$ contents in algal-bacterial AGS suggest its great potential for nutrients or resources recovery from wastewater. Moreover, the high P bioavailability (98\%) in the algal-bacterial AGS was achieved under low influent carbon condition $(\mathrm{COD} / \mathrm{N}=1)$, further demonstrating the high 
potential for $\mathrm{P}$ recovery and reutilization from the produced algal-bacterial granular biomass.

\section{Acknowledgments}

This work was supported by JSPS KAKENHI Grant Numbers JP18H03403 and JP16H06382. Mr. Ziwen Zhao would like to thank the financial support by the China Scholarship Council (No. 201708050018) for his PhD study at University of Tsukuba, Japan.

\section{Conflict of interest}

The authors declare that there is no conflict of interest regarding the publication of this article.

\section{Appendix. A. Supplementary data}

E-supplementary data for this work can be found in e-version of this paper online.

\section{References}

1. Abdel-Raouf, N., Al-Homaidan, A. A., Ibraheem, I. B. M., 2012. Microalgae and wastewater treatment. Saudi J. Biol. Sci. 19, 257-275.

2. Adav, S. S., Lee, D.-J., 2008. Extraction of extracellular polymeric substances from aerobic granule with compact interior structure. J. Hazard. Mater. 154, 1120-1126. 
3. Ahmad, J. S. M., Cai, W., Zhao, Z., Zhang, Z., Shimizu, K., Lei, Z., Lee, D.-J., 2017. Stability of algal-bacterial granules in continuous-flow reactors to treat varying strength domestic wastewater. Bioresour. Technol. 244, 225-233.

4. APHA, 2012. Standard Methods for the Examination of Water and Wastewater, American Public Health Association/American Water Work Association/Water environment Federation, Washington, D.C., USA.

5. Arsenic, A. M., Beryllium, A. M., 1996. Method 3050B Acid Digestion of Sediments, Sludges, and Soils 1.0 Scope and Application.

6. Beun, J. J., van Loosdrecht, M. C. M., Heijnen, J. J., 2002. Aerobic granulation in a sequencing batch airlift reactor. Water Res. 36, 702-712.

7. Caudan, C., Filali, A., Spérandio, M., Girbal-Neuhauser, E., 2014. Multiple EPS interactions involved in the cohesion and structure of aerobic granules. Chemosphere 117, 262-270.

8. de Godos, I., Blanco, S., García-Encina, P. A., Becares, E., Muñoz, R., 2009. Long-term operation of high rate algal ponds for the bioremediation of piggery wastewaters at high loading rates. Bioresour. Technol. 100, 4332-4339.

9. Ghangrekar, M. M., Asolekar, S. R., Joshi, S. G., 2005. Characteristics of sludge developed under different loading conditions during UASB reactor start-up and granulation. Water Res. 39, 1123-1133.

10. Gong, B., Wang, Y., Wang, J., Huang, W., Zhou, J., He, Q., 2018. Intensified nitrogen and phosphorus removal by embedding electrolysis in an anaerobic-anoxic-oxic reactor treating low carbon/nitrogen wastewater. Bioresour. Technol. 256, 562-565.

11. Guo, J., Wang, S., Lian, J., Ngo, H. H., Guo, W., Liu, Y., Song, Y., 2016. Rapid start-up of the anammox process: Effects of five different sludge extracellular polymeric substances on the activity of anammox bacteria. Bioresour. Technol. 220, 641-646.

12. Huang, W., Li, B., Zhang, C., Zhang, Z., Lei, Z., Lu, B., Zhou, B., 2015a. Effect of algae 
growth on aerobic granulation and nutrients removal from synthetic wastewater by using sequencing batch reactors. Bioresour. Technol. 179, 187-192.

13. Huang, W., Cai, W., Huang, H., Lei, Z., Zhang, Z., Tay, J. H., Lee, D.-J., 2015b. Identification of inorganic and organic species of phosphorus and its bio-availability in nitrifying aerobic granular sludge. Water Res. 68, 423-431.

14. Kocaturk, I., Erguder, T. H., 2016. Influent COD/TAN ratio affects the carbon and nitrogen removal efficiency and stability of aerobic granules. Ecol. Eng. 90, 12-24.

15. Lee, D.-J., Chen, Y. Y., Show, K. Y., Whiteley, C. G., Tay, J. H., 2010. Advances in aerobic granule formation and granule stability in the course of storage and reactor operation. Biotechnol. Adv. 28, 919-934.

16. Li, X. Y., Yang, S. F., 2007. Influence of loosely bound extracellular polymeric substances (EPS) on the flocculation, sedimentation and dewaterability of activated sludge. Water Res. $41,1022-1030$.

17. Li, X., Peng, Y., Ren, N., Li, B., Chai, T., Zhang, L., 2014. Effect of temperature on short chain fatty acids (SCFAs) accumulation and microbiological transformation in sludge alkaline fermentation with $\mathrm{Ca}(\mathrm{OH})_{2}$ adjustment. Water Res. 61, 34-45.

18. Li, B., Huang, W., Zhang, C., Feng, S., Zhang, Z., Lei, Z., Sugiura, N., 2015. Effect of $\mathrm{TiO}_{2}$ nanoparticles on aerobic granulation of algal-bacterial symbiosis system and nutrients removal from synthetic wastewater. Bioresour. Technol. 187, 214-220.

19. Liu, Y., Tay, J. H., 2002. The essential role of hydrodynamic shear force in the formation of biofilm and granular sludge. Water Res. 36, 1653-1665.

20. Liu, Q. S., Tay, J. H., Liu, Y., 2003. Substrate concentration-independent aerobic granulation in sequential aerobic sludge blanket reactor. Environ. Technol. 24, 1235-1242.

21. Liu, L., Fan, H., Liu, Y., Liu, C., Huang, X., 2017. Development of algae-bacteria granular consortia in photo-sequencing batch reactor. Bioresour. Technol. 232, 64-71. 
22. Liu, L., Zeng, Z., Bee, M., Gibson, V., Wei, L., Huang, X., Liu, C., 2018. Characteristics and performance of aerobic algae-bacteria granular consortia in a photo-sequencing batch reactor. J. Hazard. Mater. 349, 135-142.

23. Luo, J., Hao, T., Wei, L., Mackey, H. R., Lin, Z., Chen, G. H., 2014. Impact of influent $\mathrm{COD} / \mathrm{N}$ ratio on disintegration of aerobic granular sludge. Water Res. 62, 127-135.

24. Miao, L., Wang, S., Cao, T., Peng, Y., Zhang, M., Liu, Z., 2016. Advanced nitrogen removal from landfill leachate via Anammox system based on Sequencing Biofilm Batch Reactor (SBBR): Effective protection of biofilm. Bioresour. Technol. 220, 8-16.

25. Muda, K., Aris, A., Salim, M. R., Ibrahim, Z., Yahya, A., van Loosdrecht, M. C., Nawahwi, M. Z., 2010. Development of granular sludge for textile wastewater treatment. Water Res. 44, $4341-4350$.

26. Ni, B. J., Xie, W. M., Liu, S. G., Yu, H. Q., Wang, Y. Z., Wang, G., Dai, X. L., 2009. Granulation of activated sludge in a pilot-scale sequencing batch reactor for the treatment of low-strength municipal wastewater. Water Res. 43, 751-761.

27. Oehmen, A., Lemos, P. C., Carvalho, G., Yuan, Z., Keller, J., Blackall, L. L., Reis, M. A., 2007. Advances in enhanced biological phosphorus removal: from micro to macro scale. Water Res. 41, 2271-2300.

28. Pardo, P., Lopez-Sanchez, J. F., Rauret, G., 2003. Relationships between phosphorus fractionation and major components in sediments using the SMT harmonised extraction procedure. Anal. Bioanal. Chem. 376, 248-254.

29. Pronk, M., De Kreuk, M. K., De Bruin, B., Kamminga, P., Kleerebezem, R. V., van Loosdrecht, M. C. M., 2015. Full scale performance of the aerobic granular sludge process for sewage treatment. Water Res. 84, 207-217.

30. Quijano, G., Arcila, J. S., Buitrón, G., 2017. Microalgal-bacterial aggregates: applications and perspectives for wastewater treatment. Biotechnol. Adv. 35, 772-781. 
31. Ruban, V., López-Sánchez, J. F., Pardo, P., Rauret, G., Muntau, H., Quevauviller, P., 1999. Selection and evaluation of sequential extraction procedures for the determination of phosphorus forms in lake sediment. J. Environ. Monit. 1, 51-56.

32. Santiago, A. F., Calijuri, M. L., Assemany, P. P., Calijuri, M. D. C., Reis, A. J. D. D., 2013. Algal biomass production and wastewater treatment in high rate algal ponds receiving disinfected effluent. Environ. Technol. 34, 1877-1885.

33. Tang, C. C., Zuo, W., Tian, Y., Sun, N., Wang, Z. W., Zhang, J., 2016. Effect of aeration rate on performance and stability of algal-bacterial symbiosis system to treat domestic wastewater in sequencing batch reactors. Bioresour. Technol. 222, 156-164.

34. van Loosdrecht, M. C., Brdjanovic, D., 2014. Anticipating the next century of wastewater treatment. Science 344, 1452-1453.

35. Wang, D., Fu, Q., Xu, Q., Liu, Y., Ngo, H.H., Yang, Q., Zeng, G., Li, X., Ni, B.-J., 2017. Free nitrous acid-based nitrifying sludge treatment in a two-sludge system enhances nutrient removal from low-carbon wastewater. Bioresour. Technol. 244, 920-928.

36. Xie, C., Zhao, J., Tang, J., Xu, J., Lin, X., Xu, X., 2011. The phosphorus fractions and alkaline phosphatase activities in sludge. Bioresour. Technol. 102, 2455-2461.

37. Zhang, Q., Hu, J., Lee, D. J., 2016a. Aerobic granular processes: current research trends. Bioresour. Technol. 210, 74-80.

38. Zhang, Y., Ma, H., Niu, Q., Chen, R., Hojo, T., Li, Y. Y., 2016b. Effects of substrate shock on extracellular polymeric substance (EPS) excretion and characteristics of attached biofilm anammox granules. RSC Adv. 6, 113289-113297.

39. Zhang, B., Lens, P. N., Shi, W., Zhang, R., Zhang, Z., Guo, Y., Cui, F., 2018. Enhancement of aerobic granulation and nutrient removal by an algal-bacterial consortium in a lab-scale photobioreactor. Chem. Eng. J. 334, 2373-2382. 
Table

Table 1

The influent $\mathrm{COD} / \mathrm{N}$ ratios applied to the two reactors during different operation stages.

\begin{tabular}{|c|c|c|c|}
\hline \multirow{2}{*}{ Stage } & \multirow{2}{*}{$\begin{array}{l}\text { Day } \\
\text { (start-end) }\end{array}$} & \multicolumn{2}{|c|}{ Influent $\mathrm{COD} / \mathrm{N}$ ratio } \\
\hline & & $\mathrm{R}_{1}$ & $\mathrm{R}_{2}$ \\
\hline I & $0-20$ & & COD $(400 \mathrm{mg} / \mathrm{L}): \mathrm{N}(50 \mathrm{mg} / \mathrm{L})=8: 1$ \\
\hline II & $21-40$ & $\begin{array}{l}\mathrm{COD}(400 \mathrm{mg} / \mathrm{L}): \\
\mathrm{N}(50 \mathrm{mg} / \mathrm{L})=8: 1\end{array}$ & $\operatorname{COD}(200 \mathrm{mg} / \mathrm{L}): \mathrm{N}(50 \mathrm{mg} / \mathrm{L})=4: 1$ \\
\hline III & $41-65$ & & $\operatorname{COD}(100 \mathrm{mg} / \mathrm{L}): \mathrm{N}(50 \mathrm{mg} / \mathrm{L})=2: 1$ \\
\hline IV & $66-90$ & & $\operatorname{COD}(50 \mathrm{mg} / \mathrm{L}): \mathrm{N}(50 \mathrm{mg} / \mathrm{L})=1: 1$ \\
\hline
\end{tabular}




\section{Figures}

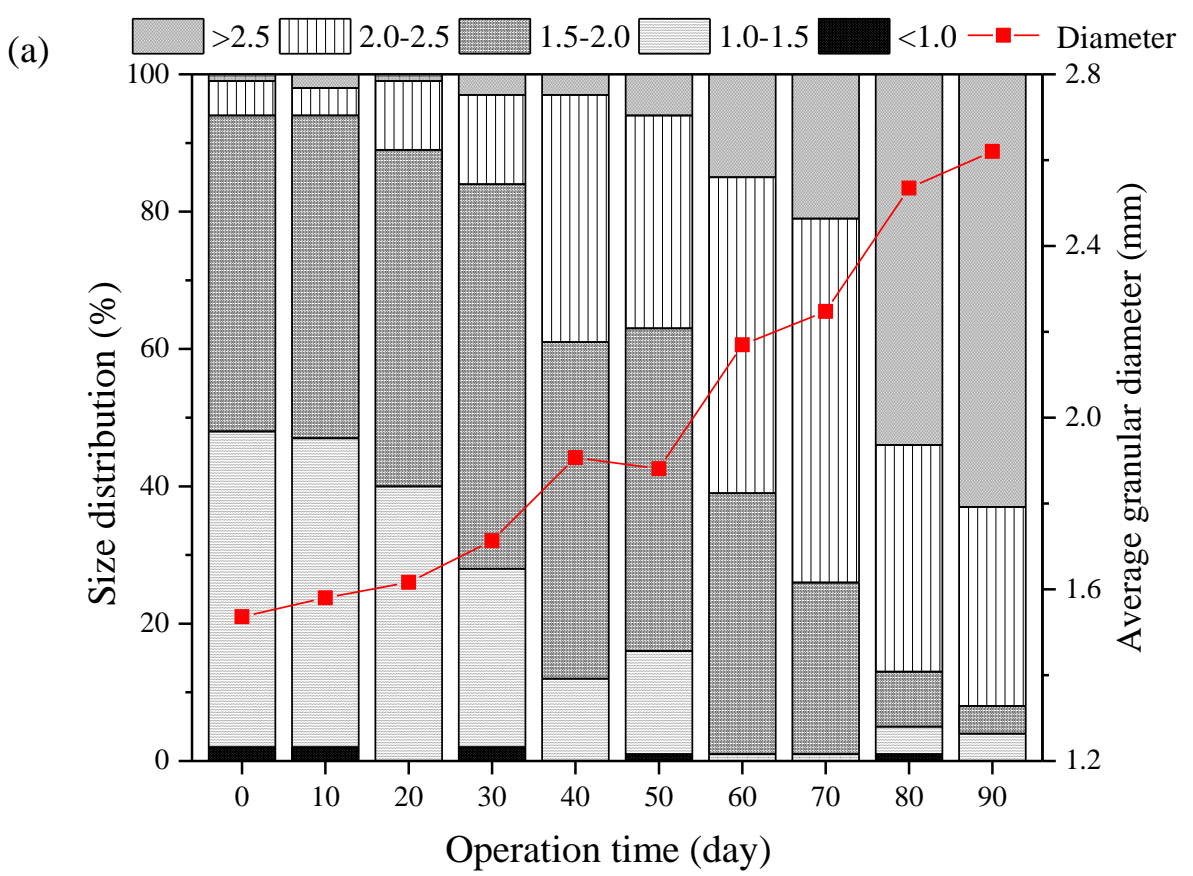

(b)

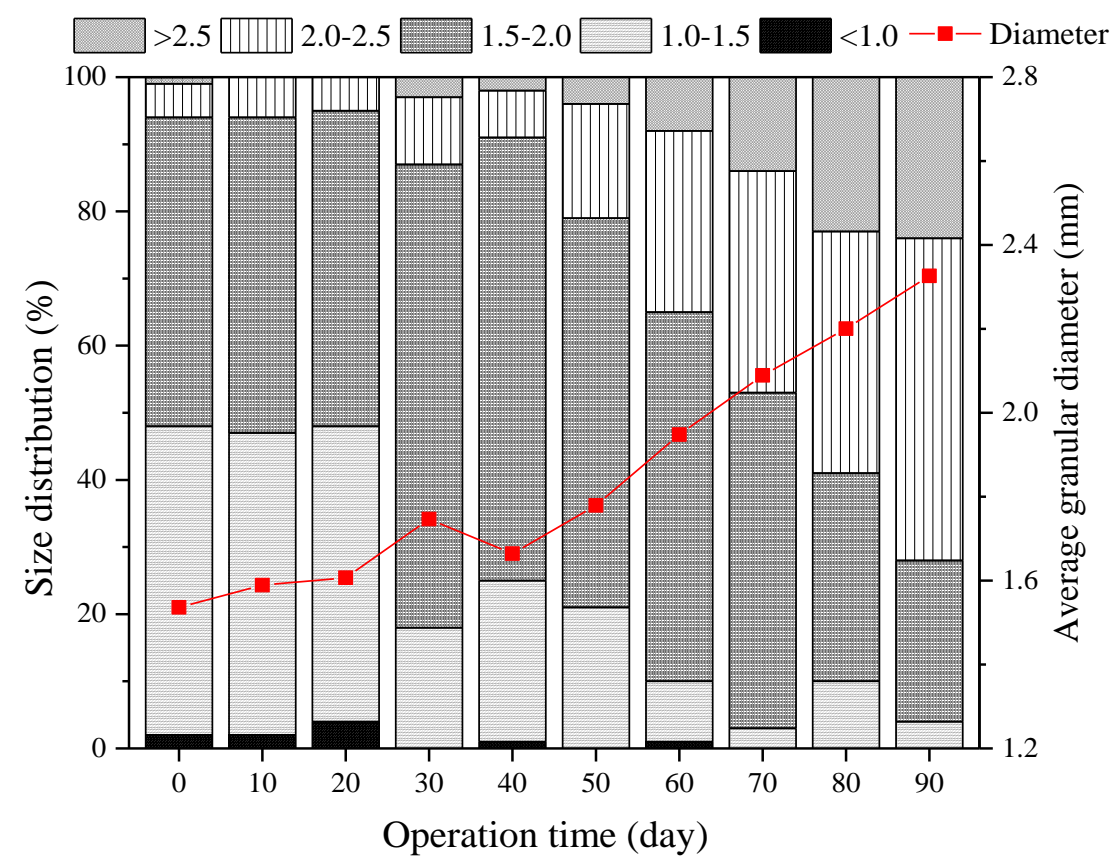


Fig. 1. Dynamic changes of algal-bacterial AGS diameter and its size distribution in $\mathrm{R}_{1}$ (a) and $R$, (h)

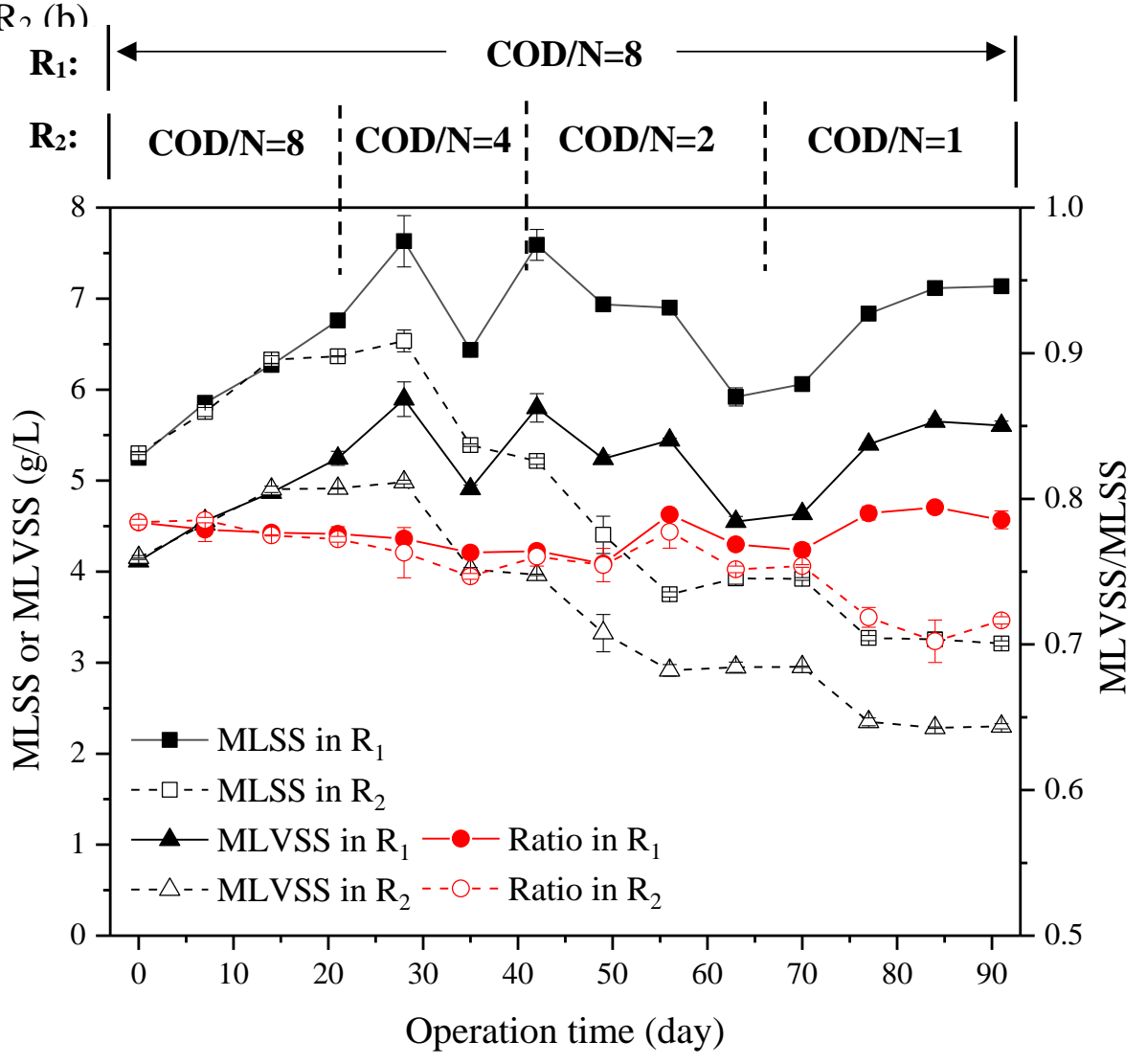


(b)

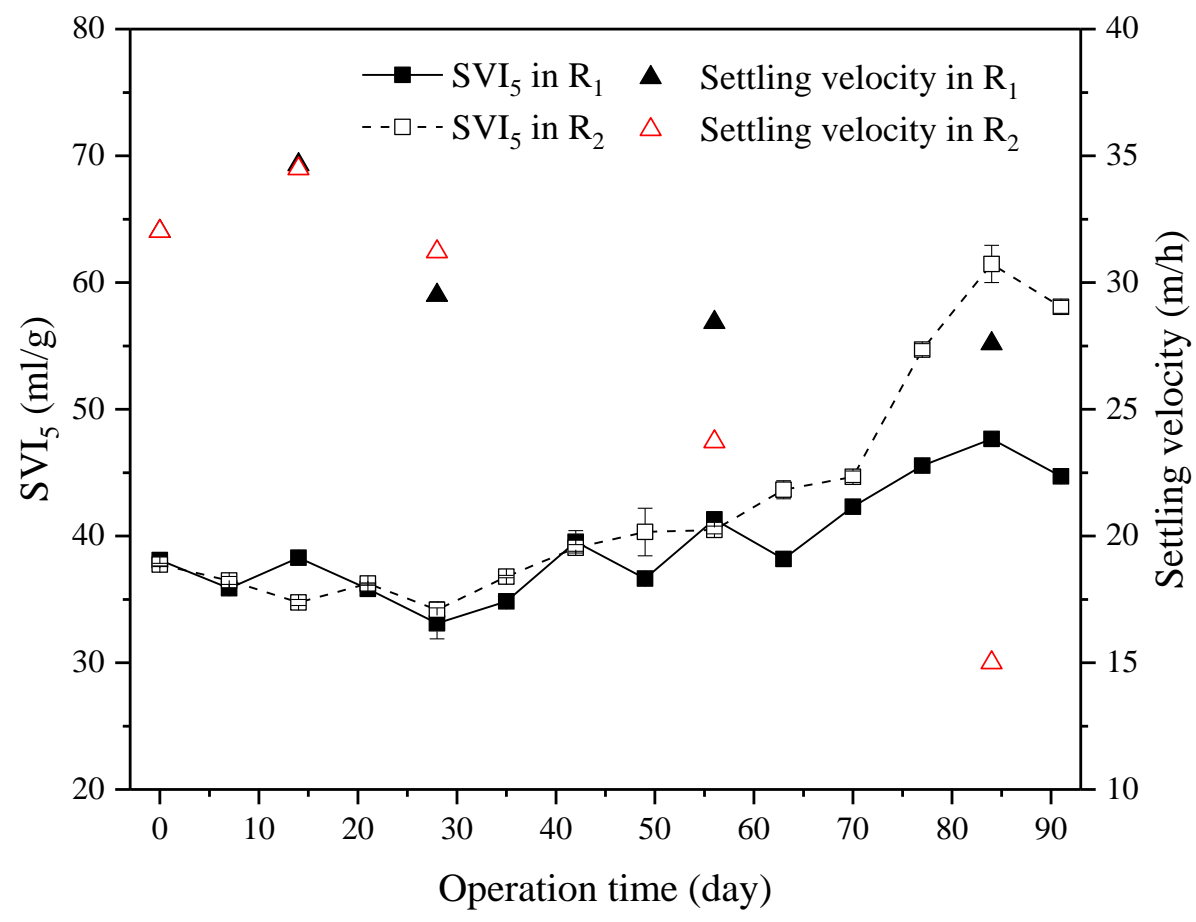


(c)

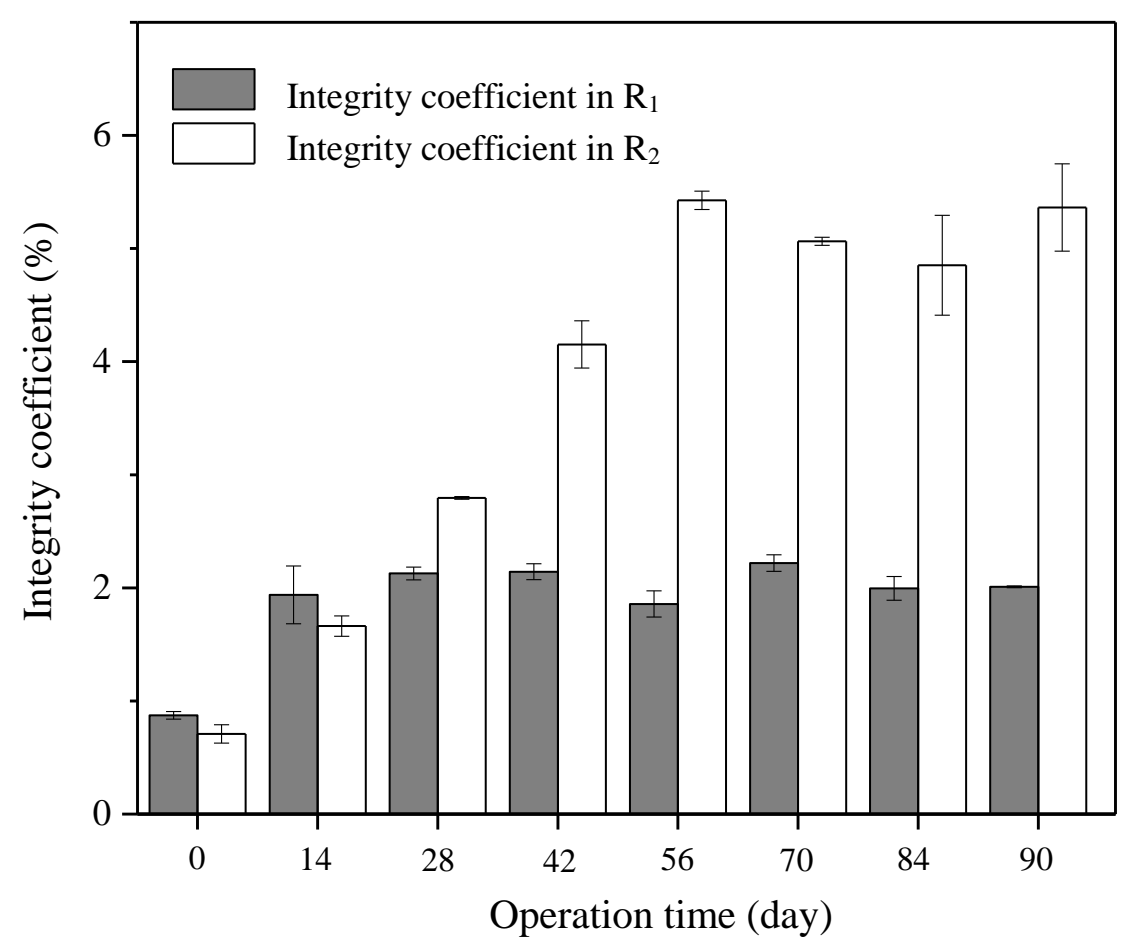

Fig. 2. Characteristics of algal-bacterial AGS in $\mathrm{R}_{1}$ and $\mathrm{R}_{2}$ during the 90 days' operation: ML(V)SS and MLVSS/MLSS ratio (a), SVI 5 and settling velocity (b), and integrity coefficient (c). 
(a)

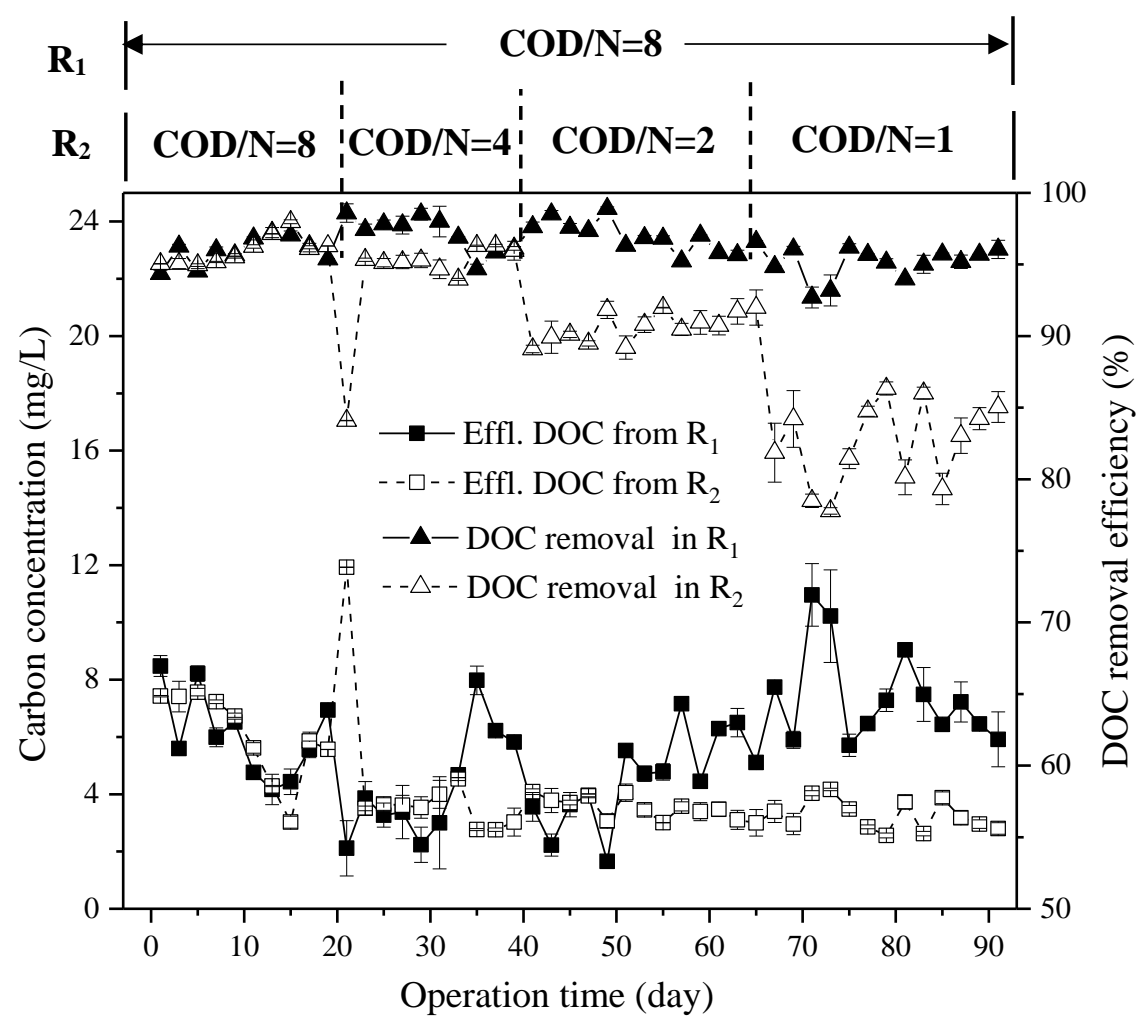

(b)

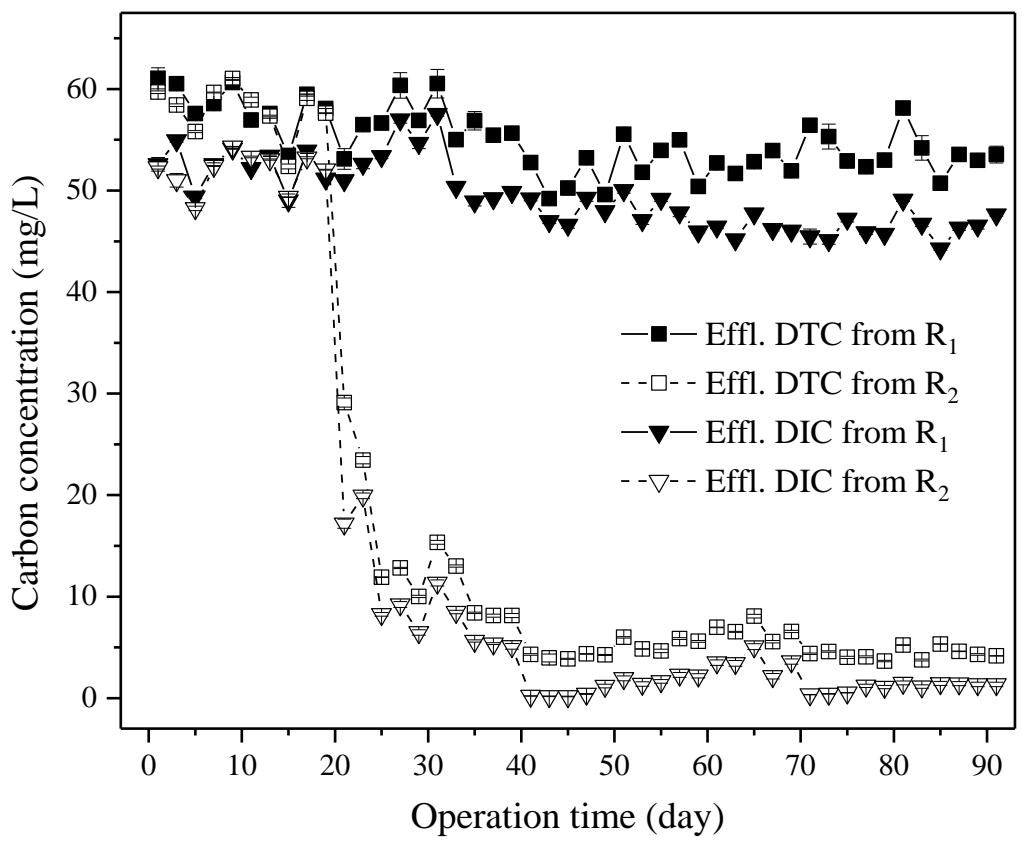


Fig. 3. Variation of effluent DOC concentration and DOC removal efficiencies (a), effluent DIC and DTC concentrations (b) in $\mathrm{R}_{1}$ and $\mathrm{R}_{2}$ during the 90 days' operation.

(a)

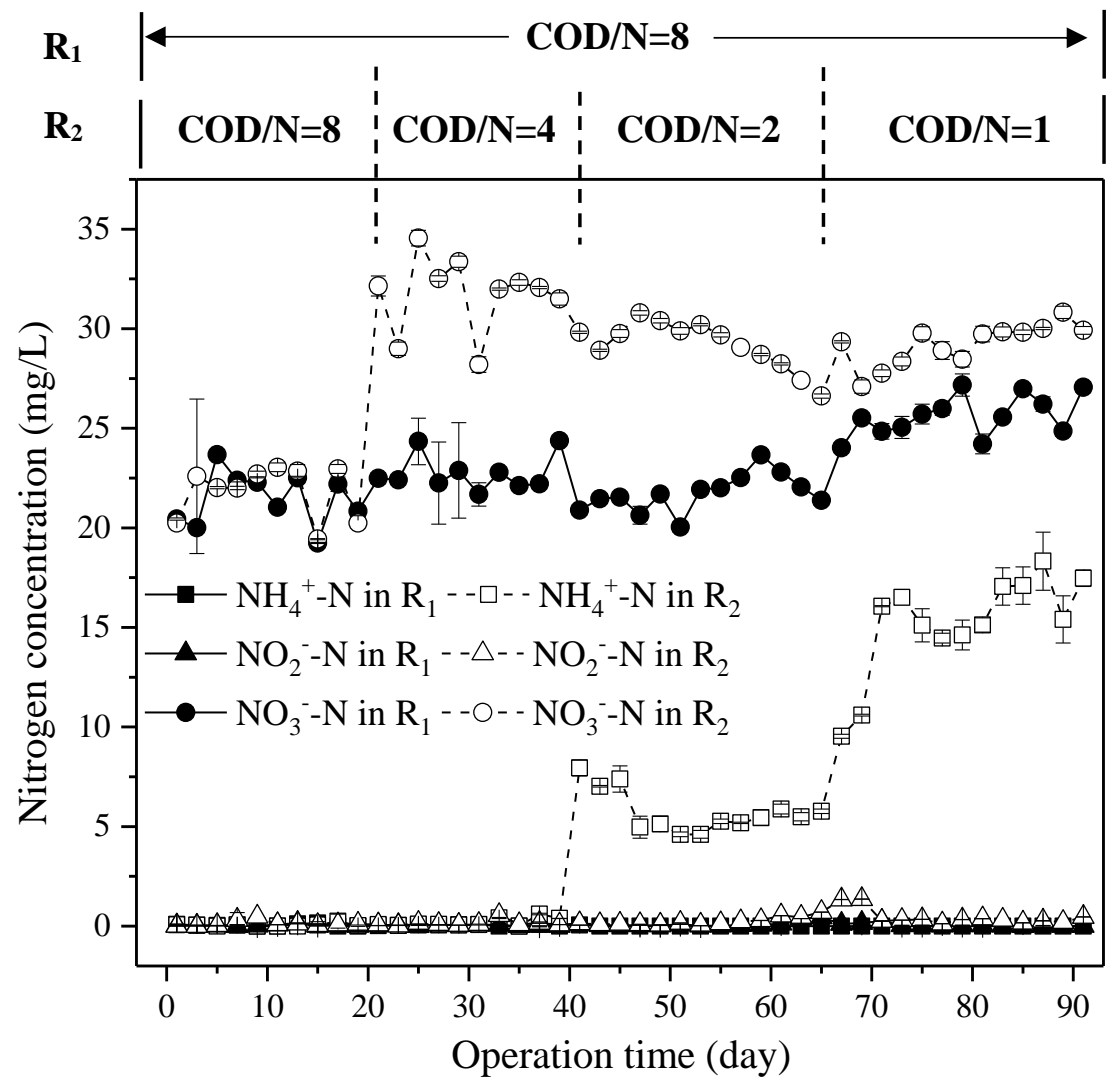


(b)

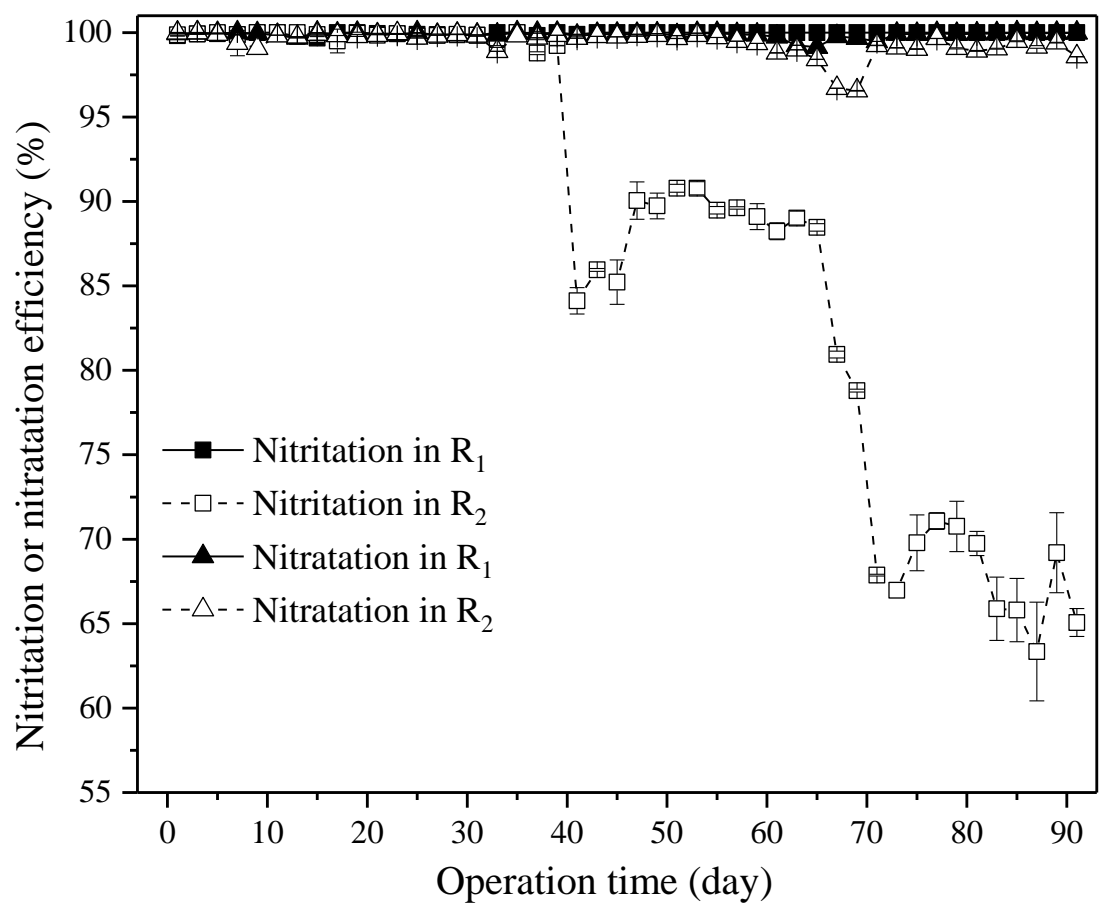

(c)

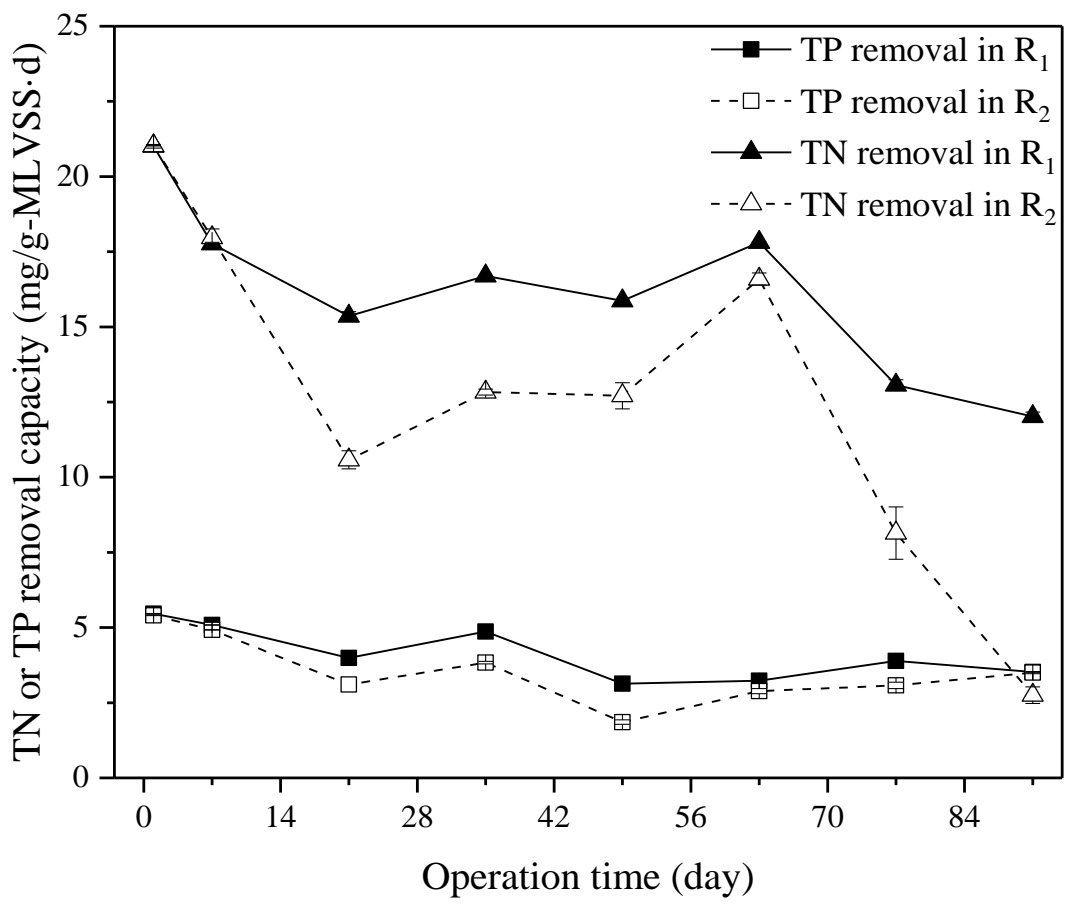


Fig. 4. Variation of effluent $\mathrm{N}\left(\mathrm{NH}_{4}{ }^{+}-\mathrm{N}, \mathrm{NO}_{2}{ }^{-} \mathrm{N}\right.$, and $\left.\mathrm{NO}_{3}{ }^{-}-\mathrm{N}\right)$ concentrations (a), nitritation and nitratation efficiencies (b), and TN and TP removal capacities (c) by $\mathrm{R}_{1}$ and $\mathrm{R}_{2}$ during the 90 days' operation.

(a)

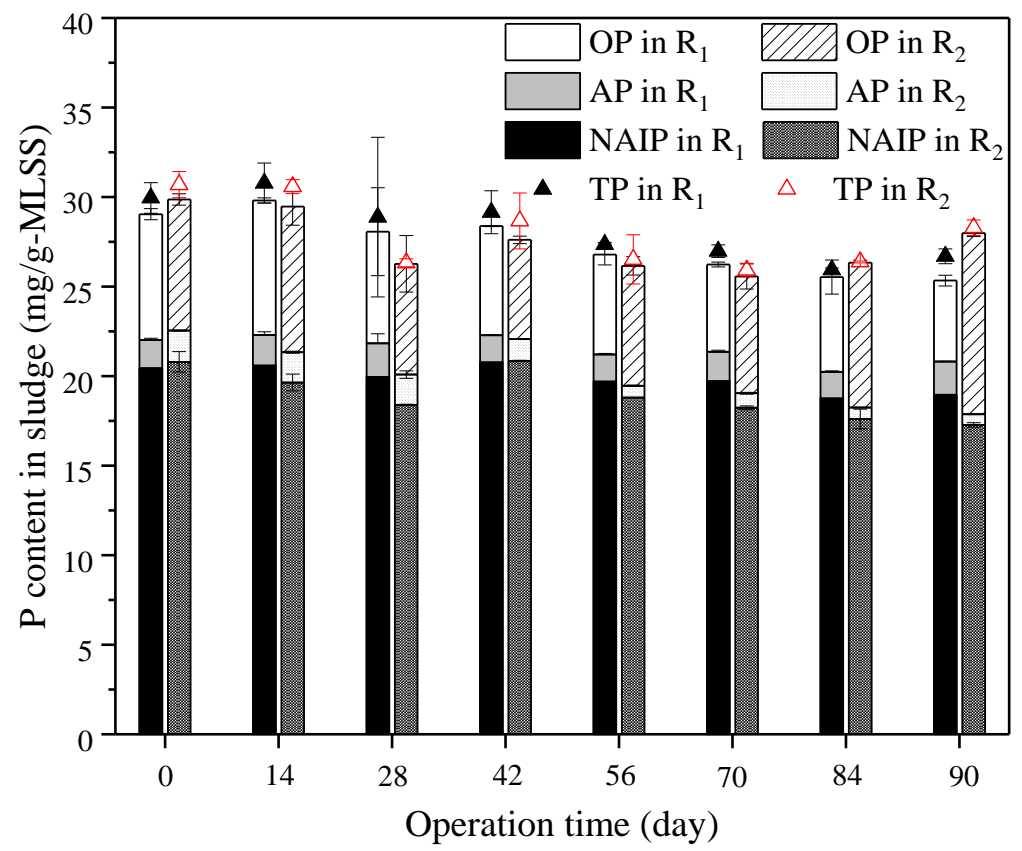


(b)

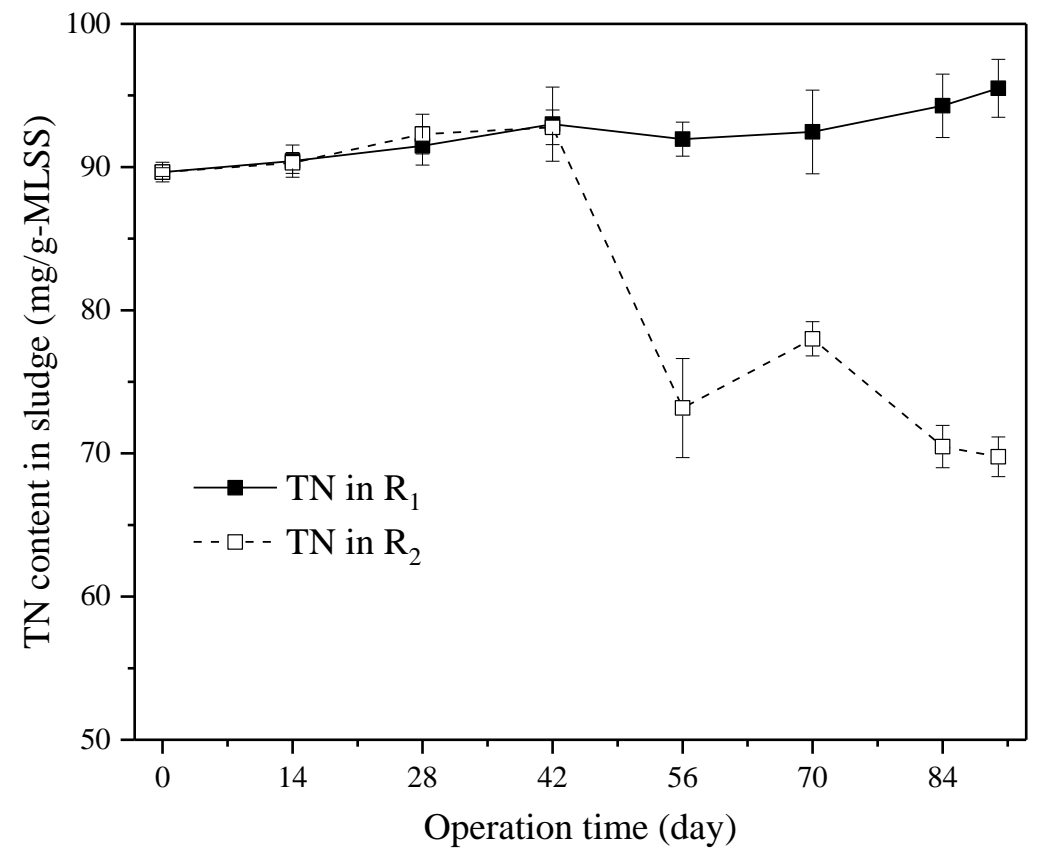

Fig. 5. Variations of $\mathrm{P}$ content and fractionation (a), and TN content (b) in the granules from $\mathrm{R}_{1}$ and $\mathrm{R}_{2}$ during the 90 days' operation. 
(a)

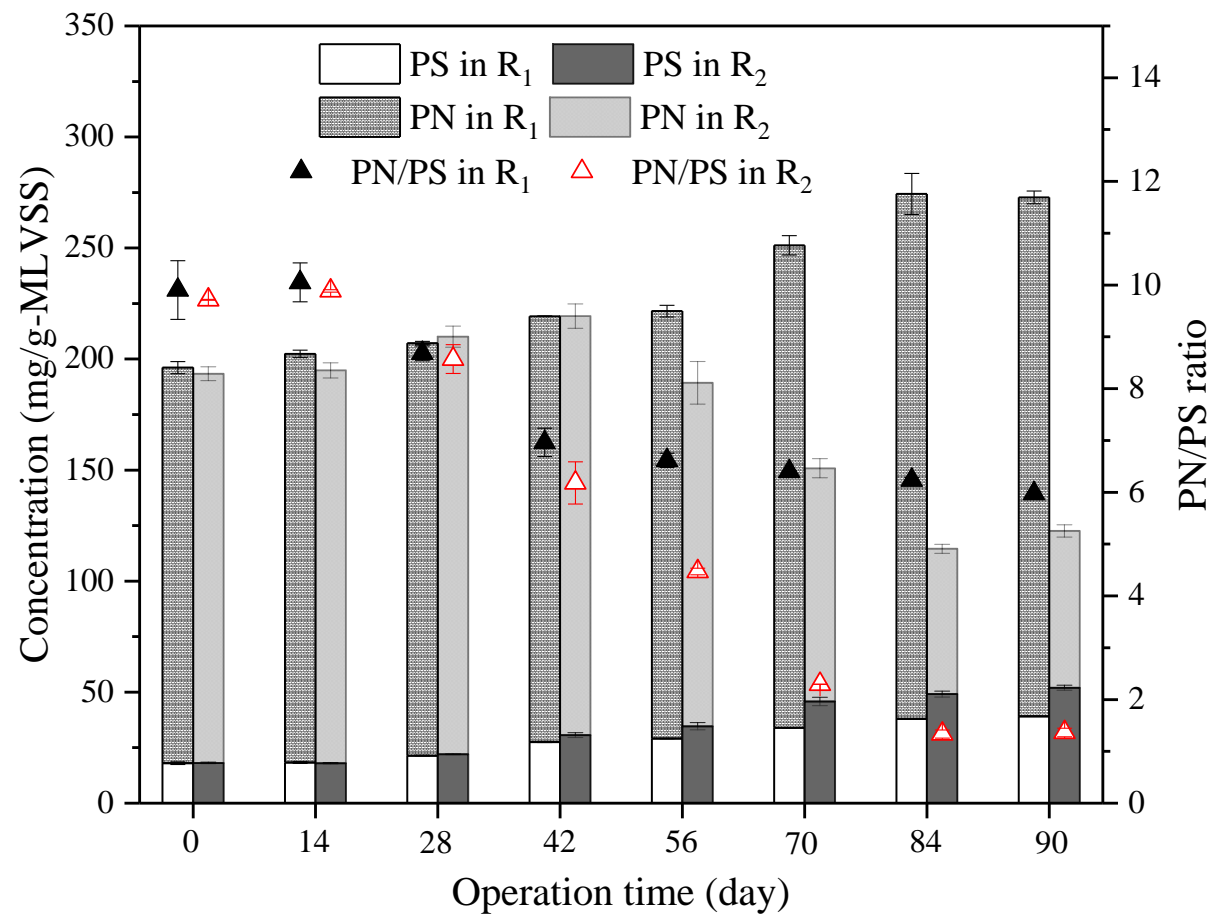

(b)

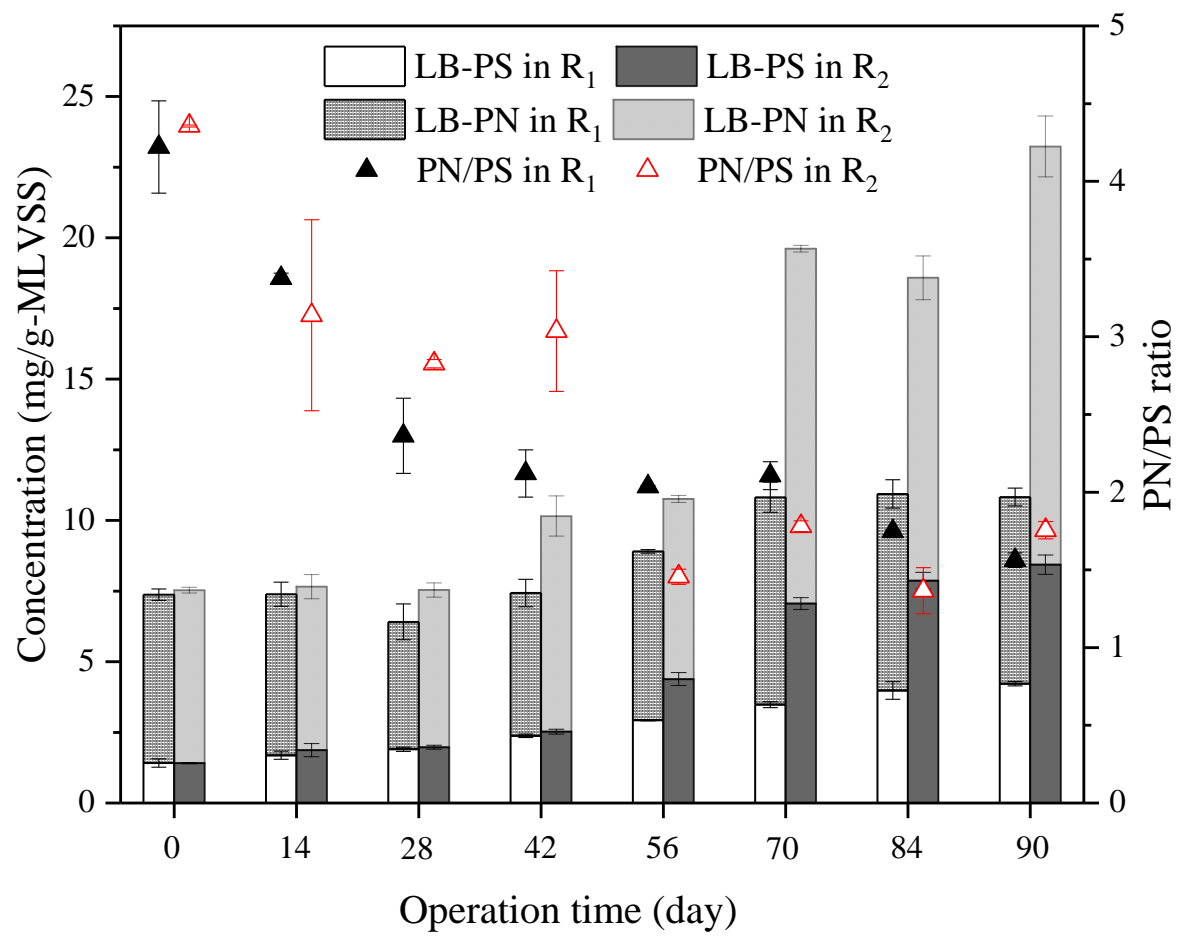


(c)

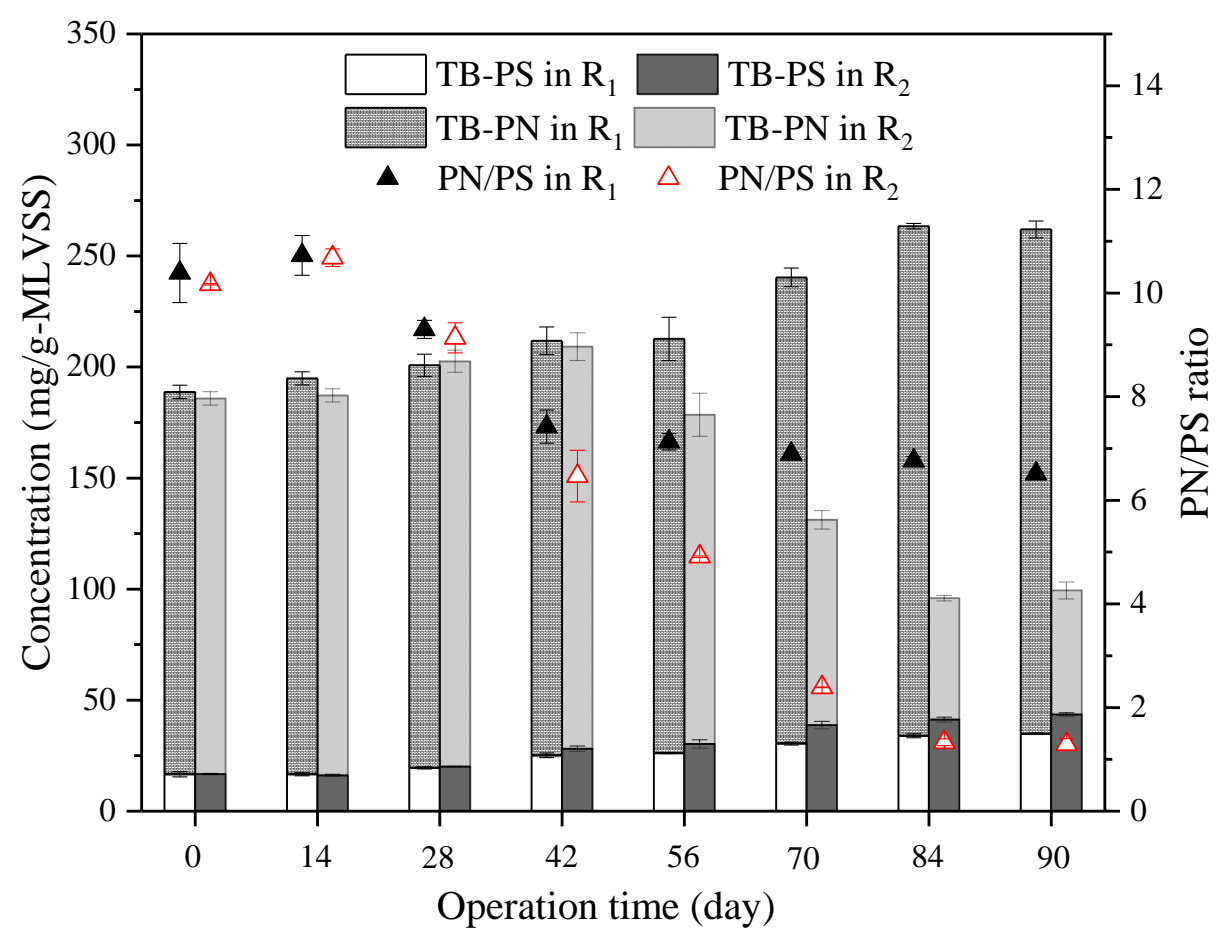

Fig. 6. Variations of total EPS (a), LB-EPS (b), TB-EPS (c), their major components (PN and PS) and corresponding PN/PS ratios during the 90 days' operation. 


\section{Supplementary Materials}

\section{Response of algal -bacterial granular system to low carbon wastewaters: Focus on granular stability, nutrients removal and accumulation}

Ziwen Zhao ${ }^{\text {a }}$, Xiaojing Yang $^{\mathrm{a}}$, Wei Cai ${ }^{\mathrm{b}}$, Zhongfang Lei ${ }^{\mathrm{a}, *}$, Kazuya Shimuzu ${ }^{\mathrm{a}}$, Zhenya Zhang $^{\mathrm{a}}$, Motoo Utsumi ${ }^{\mathrm{a}}$, Duu-Jong Lee ${ }^{\mathrm{c}}$

${ }^{\mathrm{a}}$ Graduate School of Life and Environmental Sciences, University of Tsukuba, $1 \quad-1-1$ Tennodai, Tsukuba, Ibaraki 305-8572, Japan

${ }^{\mathrm{b}}$ College of Biological and Agricultural Engineering, Jilin University, Changchun 130022, China

${ }^{\mathrm{c}}$ Department of Chemical Engineering, National Taiwan University, Taipei 106, Taiwan

*Corresponding author. Email address: lei.zhongfang.gu@u.tsukuba.ac.jp (Z. Lei) 


\section{Table S1}

Variations of the average specific oxygen utilization rate (SOUR), specific ammonia uptake rate (SAUR), nitrite uptake rate (SNUR), anaerobic $\mathrm{P}$ release rate and aerobic $\mathrm{P}$ uptake rate of granules from the reactors during the 90 days' operation.

\begin{tabular}{|c|c|c|c|c|c|c|c|c|c|c|}
\hline \multirow[t]{2}{*}{ Day* } & \multicolumn{2}{|c|}{$\begin{array}{l}\text { SAUR } \\
(\mathrm{mg}-\mathrm{N} / \mathrm{g}-\mathrm{MLVSS} \cdot \mathrm{h})\end{array}$} & \multicolumn{2}{|c|}{$\begin{array}{l}\text { SNUR } \\
(\mathrm{mg}-\mathrm{N} / \mathrm{g}-\mathrm{MLVSS} \cdot \mathrm{h})\end{array}$} & \multicolumn{2}{|c|}{$\begin{array}{l}\text { SOUR } \\
\left(\mathrm{mg}-\mathrm{O}_{2} / g-M L V S S \cdot h\right)\end{array}$} & \multicolumn{2}{|c|}{$\begin{array}{l}\text { Anaerobic } \mathrm{P} \text { release rate } \\
(\mathrm{mg}-\mathrm{P} / \mathrm{g}-\mathrm{MLVSS} \cdot \mathrm{h})\end{array}$} & \multicolumn{2}{|c|}{$\begin{array}{l}\text { Aerobic } \mathrm{P} \text { uptake rate } \\
\text { (mg-P/g-MLVSS·h) }\end{array}$} \\
\hline & $\mathrm{R}_{1}$ & $\mathrm{R}_{2}$ & $\mathrm{R}_{1}$ & $\mathrm{R}_{2}$ & $\mathrm{R}_{1}$ & $\mathrm{R}_{2}$ & $\mathrm{R}_{1}$ & $\mathrm{R}_{2}$ & $\mathrm{R}_{1}$ & $\mathrm{R}_{2}$ \\
\hline 15 & 6.18 & 6.03 & 1.85 & 1.90 & 23.3 & 24.5 & 5.89 & 6.07 & 2.28 & 2.33 \\
\hline 32 & 6.96 & 4.14 & 1.94 & 1.73 & 21.0 & 16.2 & 5.80 & 0.85 & 2.17 & 0.34 \\
\hline 58 & 7.50 & 2.41 & 2.01 & 1.89 & 19.4 & 12.4 & 6.23 & 0.04 & 2.57 & 0.03 \\
\hline 86 & 8.90 & 3.42 & 2.07 & 1.88 & 20.6 & 9.1 & 7.45 & 0.21 & 3.21 & 0.09 \\
\hline
\end{tabular}

Note: * The determination of $\mathrm{P}$ release and uptake was conducted on day $10,30,55$ and 85 , respectively. 


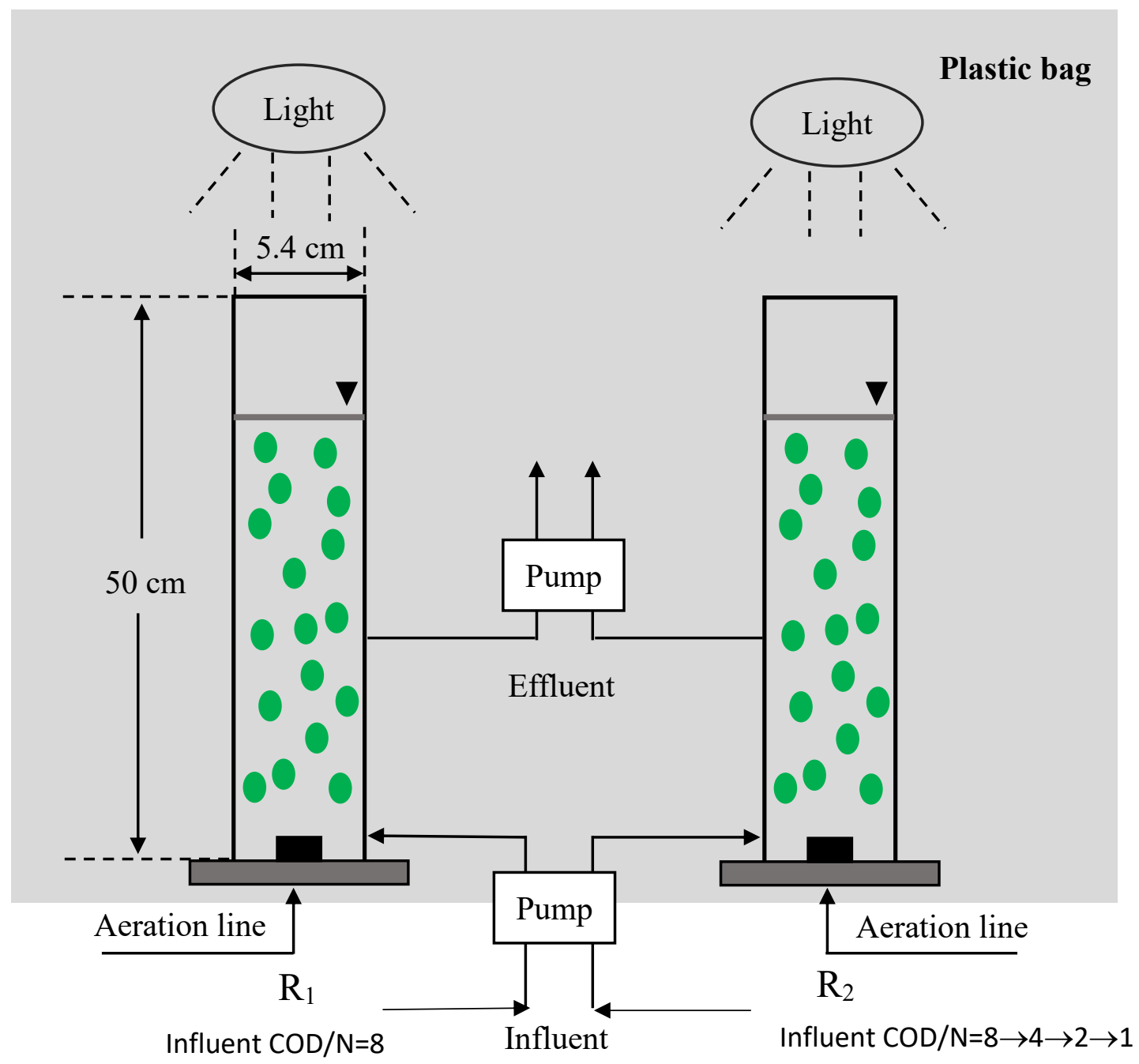

Fig. S1. Structural diagram of the SBR systems used in this study. 
Day 0

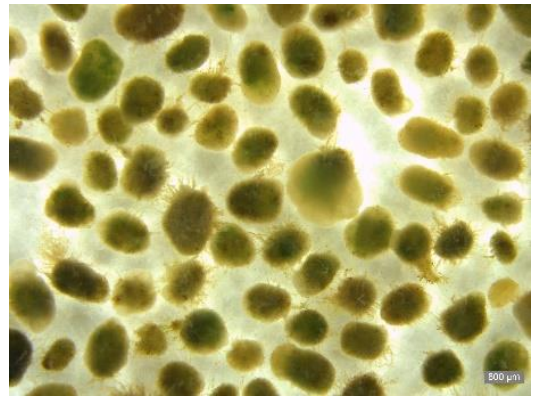

Day 30

Day 60
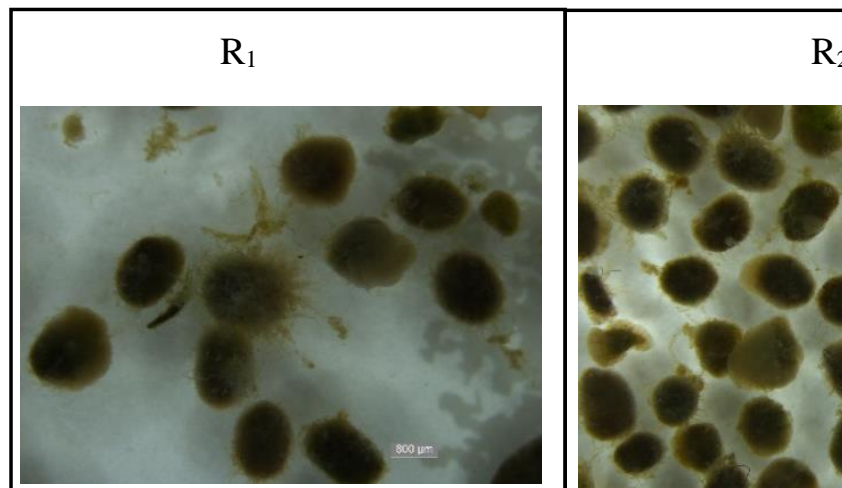

Day 90
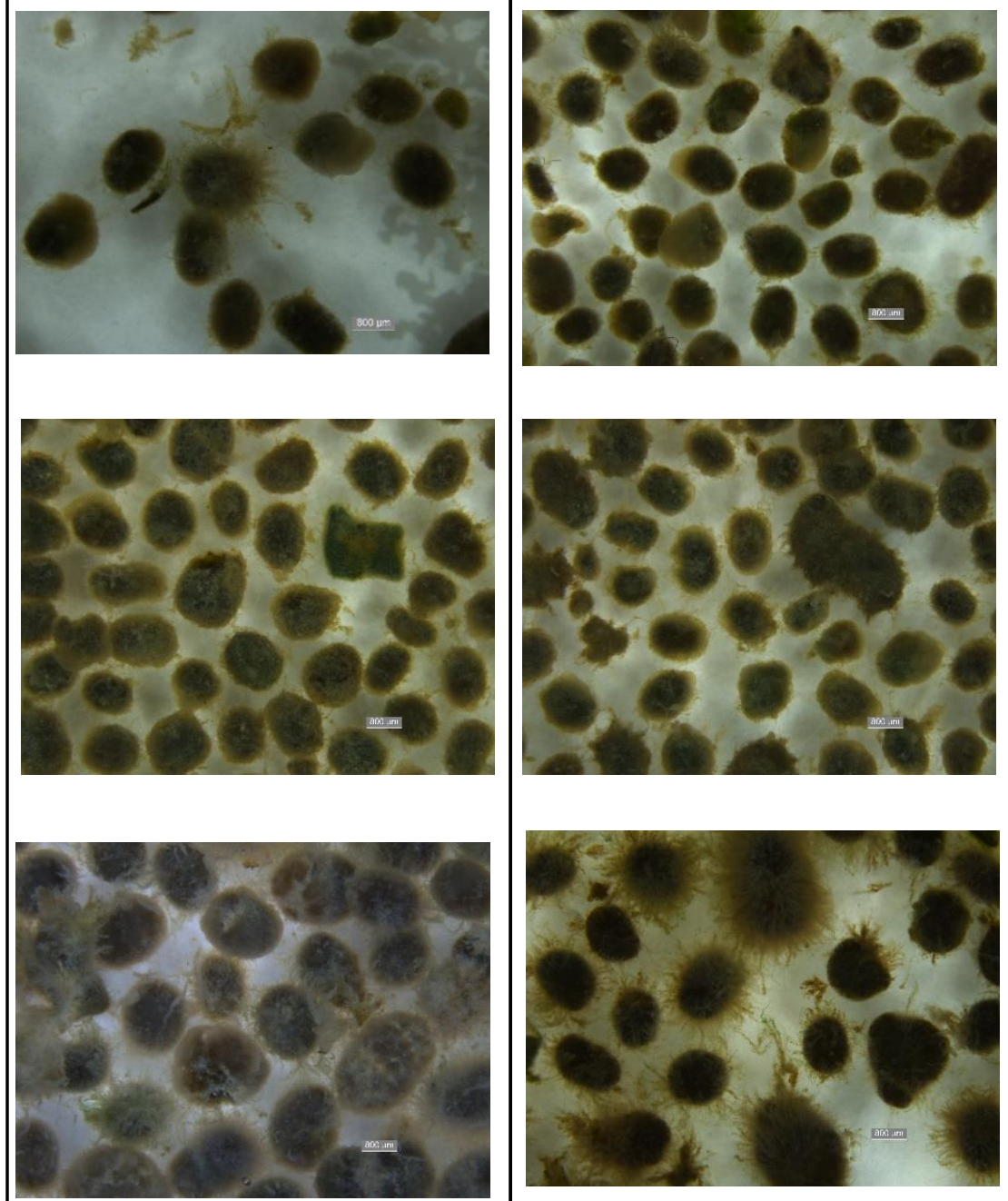

Fig. S2. Morphological changes of the algal-bacterial AGS in the two reactors on day 0, 30, 60, and 90 , respectively. 
$\mathrm{R}_{1}$-granule on day 90
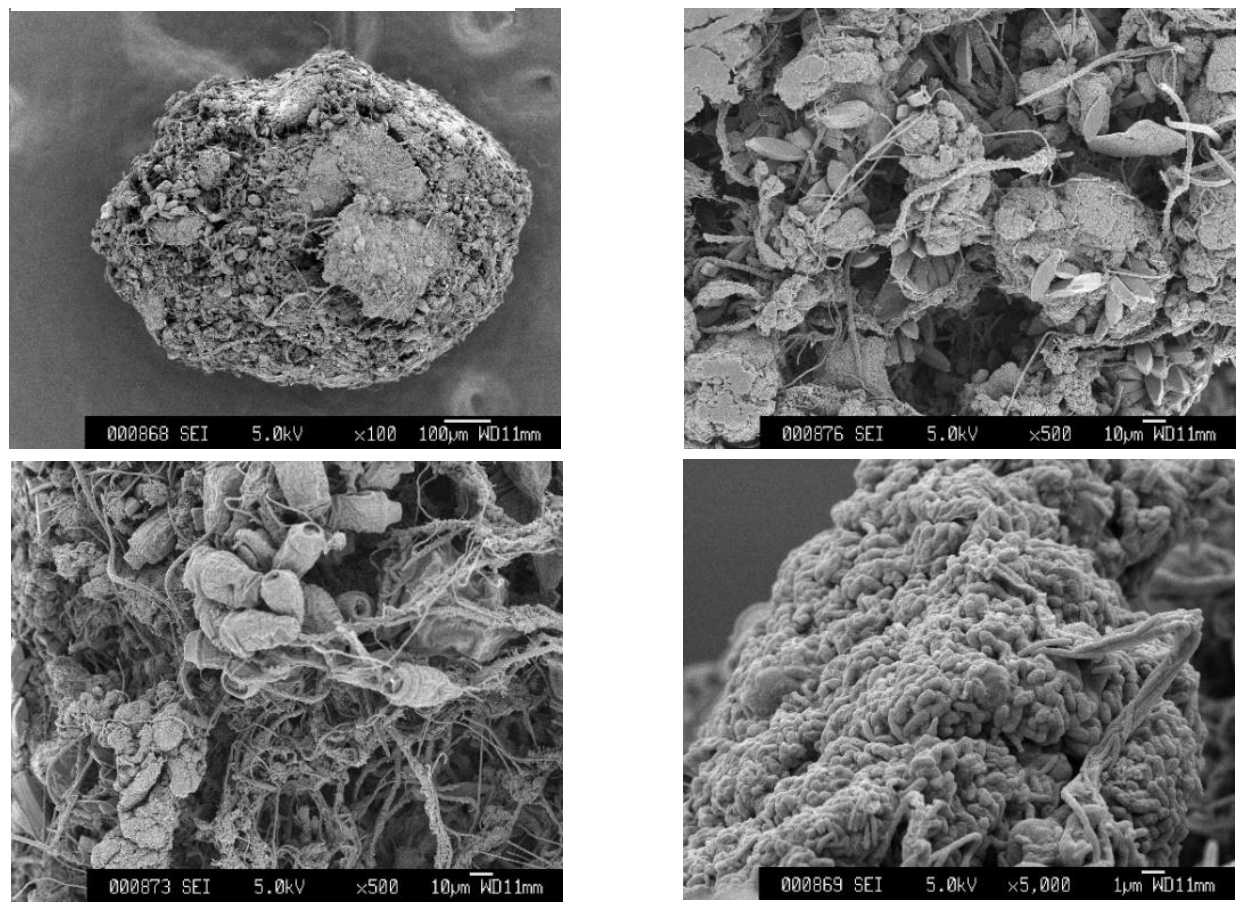

$\mathrm{R}_{2}$-granule on day 90
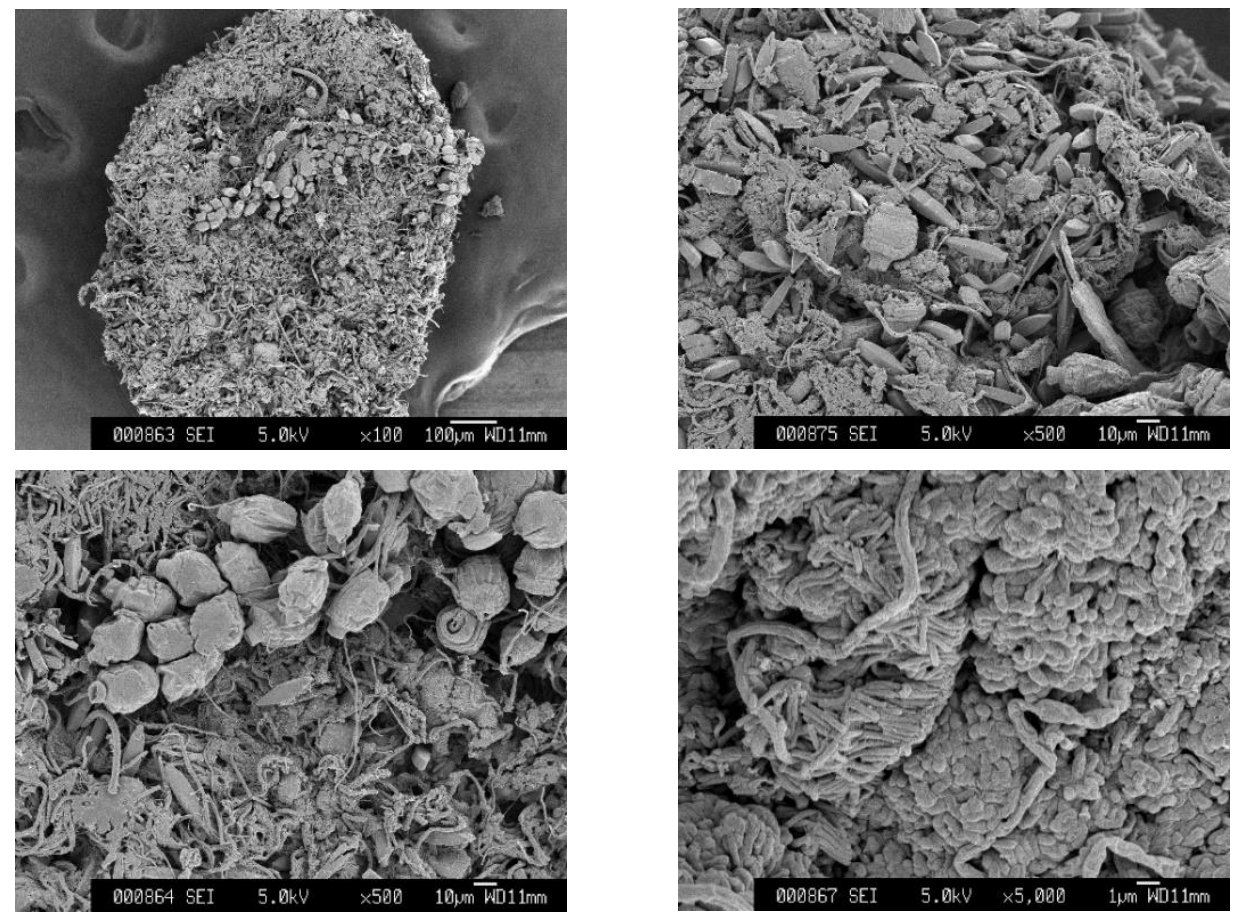

Fig. S3. Scanning electron microscopic (SEM) images of algal-bacterial AGS. 


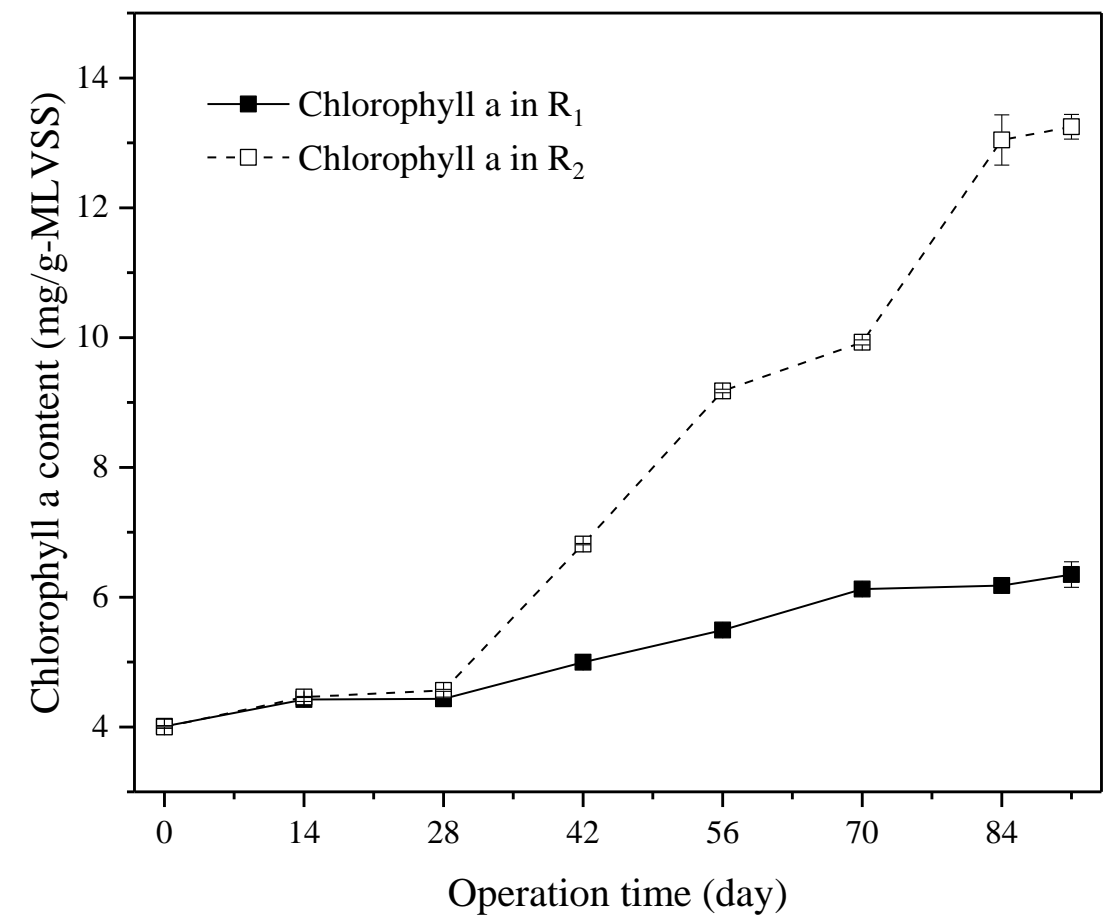

Fig. S4. Variations of chlorophyll a concentration in the granules from $R_{1}$ and $R_{2}$ during the 90 days' operation. 